\title{
ACESSO À JUSTIÇA: \\ UMA RELEITURA DA OBRA DE MAURO \\ CAPPELLETTI E BRYANT GARTH A PARTIR DO BRASIL 40 ANOS DEPOIS*
}

\author{
Aluisio Gonçalves De Castro Mendes*** \\ Larissa Clare Pochmann Da Silva****
}

\begin{abstract}
RESUMO
O projeto Florença, coordenado por Mauro Cappelletti, em colaboração com Bryant Garth e Nicolò Trocker, foi de extrema relevância para o estudo do direito processual, retratando, a partir de estudos empíricos, em três ondas renovatórias, os entraves para o acesso à Justiça. Quarenta anos após o início da divulgação das
\end{abstract}

Recibido: enero 31 de 2015 - Aceptado: junio 30 de 2015

* Artículo inédito. Artigo elaborado em dezembro de 2014 e revisado em junho de 2015.

*:* Pós-Doutor pela Universidade de Regensburg, Alemanha. Doutor em Direito pela UFPR. Mestre em Direito pela UFPR. Mestre em Direito pela Johann Wolfgang Goethe Universität (Frankfurt AM Main, Alemanha). Especialista em Direito Processual Civil pela Universidade de Brasília (UnB). Professor nos cursos de graduação e pós-graduação da Universidade do Estado do Rio de Janeiro (UERJ) e da Universidade Estácio de Sá (Unesa). Diretor do Instituto Brasileiro de Direito Processual (IBDP). Membro do Instituto Ibero-americano de Direito Processual, da Associação Brasil-Alemanha de Juristas e da International Association of Procedural Law. Ex-Promotor de Justiça. Desembargador Federal. Diretor de Cursos e Pesquisas da Escola da Magistratura Regional Federal da $2^{a}$ Região (EMARF). Membro do Conselho Superior da Escola Nacional de Formação e Aperfeiçoamento de Magistrados (Enfam).

*** Graduada em Direito pela Universidade do Estado do Rio de Janeiro (UERJ). Mestre e Doutoranda em Direito pela Universidade Estácio de Sá (UNESA). Membro do Instituto Brasileiro de Direito Processual (IBDP). Professora no curso de graduação da Universidade Candido Mendes (UCAM), campi Tijuca e Jacarepaguá. Advogada. 
pesquisas, busca-se verificar a situação desses entraves hoje, se foram resolvidos ou se ainda subsistem, e em que medida permanecem.

Palavras-chave: Acesso à Justiça; Ondas Renovatórias; Releitura.

\begin{abstract}
Project Florence, coordinated by Mauro Cappelletti, together with Bryant Garth and NicolòTrocker, was very important for the study of procedural law, mentioning, through empirical data, in three renewals waves, the barriers to access to justice. Forty years after the start of the spreading of the research, this work try to check the status of these obstacles today, if they continue or not, and how they remain.
\end{abstract}

Keywords: Access to Justice; renewal waves; re-reading.

\title{
INTRODUÇÃO.
}

O acesso à Justiça é uma preocupação constante ao longo da história, mas a obra de Mauro Cappelletti, em colaboração com Bryant Garth e NicolòTrocker, publicada em 4 (quatro) volumes, em anos distintos, a partir de 1974/1975, foi um marco para o direito processual, ao realizar, em conjunto com estudiosos de diversos países, uma abordagem nova sobre o acesso à Justiça na sociedade contemporânea. A pesquisa, denominada Projeto Florença, detectou diversas barreiras para a efetividade do acesso à Justiça.

A partir dessas constatações, foram sistematizadas três ondas renovatórias de acesso à Justiça, que emergiram em sequência cronológica. A primeira onda renovatória envolve a assistência jurídica; a segunda envolve a representação jurídica para os interesses difusos, especialmente nas áreas de proteção ambiental e de direito do consumidor; e a terceira, denominada "enfoque de acesso à justiça”, reflete a tentativa de atacar as barreiras ao acesso à Justiça.

Quarenta anos após o início da divulgação das pesquisas, realiza-se uma releitura dessas ondas renovatórias, tendo o Brasil como foco, mas tentando-se, apesar da dificuldade de pesquisas empíricas que adotem os mesmos critérios ${ }^{1}$, comparar ao cenário internacional. Para isso, inicia-se com a abordagem da importância da obra de Mauro Cappelletti para o direito processual, seguindo-se com a abordagem de cada uma das três ondas renovatórias.

1 As pesquisas localizadas em diversos países muitas vezes fornecem dados distintos e utilizam métodos diferentes, o que gera alguma dificuldade para comparação. Ademais, nem sempre as reformas jurídicas foram precedidas de um estudo que considerasse as características sociais, econômicas ou históricas dos países. 


\section{A RELEVÂNCIA DA OBRA DE MAURO CAPPELLETTI E BRYANT GARTH NO CONTEXTO DO ACESSO À JUSTIÇA.}

O acesso à Justiça não é uma preocupação recente ao longo da história da humanidade ${ }^{2}$ e significa tanto o sistema onde os cidadãos buscam assegurar seus direitos como onde submetem seus conflitos ao Estado ${ }^{3}$, mas sofreu uma mudança no estudo e no ensino do direito processual civil. A concepção tradicional sobre o tema estava atrelada aos direitos individuais, limitada ao direito formal de ajuizar uma ação e de apresentar defesa quando da condição de réu. $\mathrm{O}$ acesso à Justiça seria um direito natural e, portanto, não demandaria uma atuação estatal para assegurá-lo, permanecendo o Estado passivo em relação a problemas como a aptidão de uma pessoa para reconhecer seus direitos e defendê-los adequadamente ${ }^{4}$.

Nesse contexto, não havia uma preocupação com as custas do litígio, especialmente em relação àqueles que não poderiam arcar com ele, e nem mesmo em arcar com os custos de um corpo de profissionais para atuar em juízo. O estudo era formalista e a preocupação estava centrada na teoria do procedimento, sem verificar seus efeitos na prática forense. Dessa forma, as preocupações eram nitidamente afastadas da realidade da maior parte da população, que poderia até ter direitos formalmente reconhecidos, mas não o acesso a uma justiça substantiva ${ }^{5}$.

Com a passagem do Estado Liberal para o Estado Social, o acesso à Justiça foi reconhecido como um direito, responsável por proteger os direitos que já estavam legalmente assegurados ${ }^{6}$. $\mathrm{O}$ acesso à Justiça passa, então, a ser reconhecido como requisito fundamental para assegurar - e não apenas proclamar

2 CARnEIRO, Paulo Cezar Pinheiro. Acesso à Justiça: Juizados Especiais Cíveis e Ação Civil Pública. Uma Nova Sistematização da Teoria Geral do Processo. 2. ed. Forense, 2007.

3 CAPPELletTI, Mauro, GARTH, Bryant. Access to Justice: A World Survey. vol. 1, Milão: Sitjoff and Noordhoff, 1978. p. 6.

4 CAPPELLETTI, Mauro, GARTH, Bryant. Acesso à Justiça. Porto Alegre: Sergio Antonio Fabris Editor, 2002, p. 9.

5 GALANTER, Marc. The Travails of Total Justice. In: GORDON, Robert W; HORWITZ, Morton J. Law, Society, and History: Themes in the Legal Sociology and Legal History of Lawrence M. Friedman. Cambridge: Cambridge University Press, 2011. pp. 103-117.

6 CAPPELLETTI, Mauro, GARTH, Bryant, TROCKER, Nicolò. Rabels Zeitschrift für ausländisches und internationales Privatrecht / The Rabel Journal of Comparative and International Private Law 40. Jahrg., H. 3/4, Der Schutz des Schwächeren im Recht, 1976, p. 672. Disponível em http://www.jstor.org/discover/10.2307/27876038?sid=211 
- direitos ${ }^{7}$. Porém, não havia uma preocupação com sua efetividade. Era preciso reconhecer que a técnica processual serve a funções sociais; que os tribunais não são a única forma de solucionar conflitos e que a regulamentação processual, inclusive a criação ou o encorajamento de alternativas ao sistema judiciário, tem efeitos sobre como opera a lei substantiva ${ }^{8}$.

Nessa perspectiva, a obra de Mauro Cappelletti, em colaboração com Bryant Garth e NicolòTrocker, publicada em 4 (quatro) volumes, em anos distintos, a partir de 1974/1975,foi de extrema importância para a estruturação do tema, revelando-se um verdadeiro marco para o estudo do direito processual. Apesar da extensão e da relevância em sua íntegra da pesquisa, apenas o último volume, assinado por Mauro Cappelletti e Bryant Garth, que representou a conclusão dos estudos do denominado Projeto Florença -na verdade, essa denominação representou a reunião de um conjunto de projetos de pesquisa centralizado em Florenç $\mathrm{a}^{9}-$, foi traduzido para o português, sendo divulgado no Brasil através de tradução realizada pela hoje Ministra aposentada do Supremo Tribunal Federal Ellen Gracie Northfleet ${ }^{10}$.

O objetivo do estudo era delinear o surgimento e desenvolvimento de uma abordagem nova e compreensiva do acesso à Justiça na sociedade contemporânea, baseada na ruptura com a crença tradicional da confiabilidade das instituições jurídicas e no desejo de tornar efetivo o direito de todos os cidadãos ${ }^{11}$, especialmente porque, na época de desenvolvimento do projeto, eram frequentemente denegados o acesso à Justiça no reconhecimento de direitos relacionados ao meio ambiente e dos consumidores ${ }^{12}$. O projeto de pesquisa resultou em um relatório comparativo sobre o acesso à Justiça, com escala mundial, preparado em Florença, na Itália, a partir do outono de 1973, envolvendo100 experts de 27 países ${ }^{13}$.

As conclusões do projeto representaram uma importante transformação na compreensão do acesso à Justiça, sendo detectadas algumas barreiras para

04927538241 \&uid $=3 \&$ uid $=2 \&$ uid $=60 \&$ uid $=4579946967 \&$ uid $=70 \&$ uid $=4579946977 \&$ uid=2134. [Acesso em $20 \mathrm{dez}$. 2014].

7 CAPPELLETTI, Mauro. Acesåso à Justiça. Op. cit. p. 12.

8 Ibídem.

9 CAPPELlETTI, Mauro. Access to Justice and the Welfare State. Firenza: European University Institute, 1981. p. 2.

10 CAPPElletTi, Mauro, GARTH, Bryant. Acesso à Justiça. Porto Alegre: Sergio Antonio Fabris Editor, 2002.

11 Ibídem. p. 9.

12 CAPPELLETTI, Rabels Zeitschrift für... Op. cit. p. 669.

13 Ibídem. p. 670. 
sua efetividade. A primeira barreira identificada foi o custo, aí incluindo tanto os custos para movimentar o aparato judiciário como os custos de arcar com os honorários de um advogado. A mais importante despesa de um litigante consistia, na época da pesquisa, nos honorários advocatícios: os custos de um advogado, no Canadá e nos Estados Unidosvariavam de 25 a 300 dólares a hora $^{14}$.

A regra de quem perde ressarce as custas, que prevalece na maioria dos países, também foi capaz de inibir muitas demandas, de cidadãos receosos com o resultado do julgamento de suas causas. Sem a certeza de serem vencedores, os autores acabavam inibidos de irem ao Judiciário por não terem condições de arcar com os custos da parte contrária ${ }^{15}$. Por outro lado, o sistema americano, que não possuía a previsão do perdedor arcar com as custas, também não representaria, pelo menos em tese, uma vantagem, pois, caso houvesse êxito, não haveria o ressarcimento das custas pagas.

Ainda em relação aos custos, as causas mais afetadas eram as pequenas demandas: muitas vezes, o benefício econômico com a demanda seria menor do que seus custos, o que poderia desincentivar a busca pela reparação de pequenas lesões. O causador do dano sabe, de antemão, que nem todos os ofendidos ingressarão em juízo e, mais ainda, que nem todos que ingressarem em juízo sairão vencedores ao final da demanda, seja por faltarem à audiência, seja por dificuldade na produção da prova, seja pela contratação de um advogado pouco experiente ${ }^{16}$. Os dados reunidos pelo Projeto Florença indicam que a relação entre os custos a serem enfrentados na ação cresce na medida em que se reduz o valor da causa. Na Alemanha, por exemplo, os custos de uma ação de US\$ 100 à época do projeto, no sistema judiciário, estava estimada em US\$ 150, enquanto os custos de uma causa de US\$ 5.000 estaria estimado em US\$4.200 ${ }^{17}$.

Além disso, o tempo também foi considerado um problema para o acesso à Justiça. Aguardar, em média, 3 (três) anos por uma resposta jurisdicional poderia ameaçar o próprio direito pleiteado, que chegaria, em alguns casos, até mesmo a perecer na espera de apreciação judicial. Ainda, o tempo seria capaz de aumentar o custo para as partese pressiona os economicamente os mais

14 CAPPELLETTI. Acesso à Justiça. Op. cit. p. 18.

15 Ibídem. pp. 16-17.

16 GALANTER, Marc. Whythe "'Haves' Come Out Ahead: Speculations on thelimits of legal change". Law and Society Review. Amherst, n. 9, 1974, p. 6. Disponível em: http://marcgalanter.net/documents/papers/whythehavescomeoutahead.pdf. [Acesso em: 13 jun. 2015]. 
fracos a abandonarem suas causas ou a aceitarem acordos em valores muito inferiores ao que teriam direito, apenas para terem uma solução o seu pleito. Para um acesso à Justiça eficaz, era preciso uma resposta jurisdicional célere ${ }^{18}$.

Haveria, ainda, uma desigualdade em relação ao cidadão que, em virtude de determinada questão, precisa acessar o Poder Judiciário e os litigantes habituais. A litigância habitual, nesse momento, já era um problema grave e que estava sendo revisitado, pois, como os próprios autores creditam, a distinção entre litigantes habituais (repeat players) e os litigantes eventuais (oneshotters) foi feito pelo norte-americano Marc Galanter. Alguns cidadãos gozam de uma série de vantagens estratégicas, por exemplo: os litigantes habituais teriam mais experiência com o litígio em juízo, estariam economicamente melhor preparados para o litígio e seriam detentores de mais informações sobre a real proporção dos danos causados ${ }^{19}$. Os advogados dos litigantes habituais costumam ser especializados na defesa do cliente e realizam estudos estratégicos sobre as chances do argumento ser acolhido ou não, com prévia experiência até mesmo sobre o patamar das condenações para barganhar em uma proposta de acordo $^{20}$, além de já serem mais conhecidos nos fóruns, o que pode permitir que sejam tratados com maior atenção e maior benevolência ${ }^{21}$. Enquanto isso, litigantes não habituais poderiam ter dificuldade de informação para reconhecerem que possuem direito, para buscarem o Poder Judiciário, além de não possuírem informação sobre como ajuizar uma demanda. $\mathrm{O}$ advogado contratado geralmente não é especializado, mas apenas apto a defender qualquer tipo de demanda ${ }^{22}$. O Projeto Florença, através de uma pesquisa realizada na província de Quebec, no Canadá, constatou que 11\% dos entrevistados disseram que jamais iriam a um advogado ${ }^{23}$.

Mais uma barreira identificada foi a legitimidade para a proteção dos direitos difusos, especialmente a legitimidade para a sua tutela, e a falta de informação sobre a sua tutela ou, simplesmente, ser capaz de desenvolver uma boa estratégia para o litígio ${ }^{24}$. $O$ processo não estaria preparado para litígios de grande escala.

18 CAPPELLETTI. Rabels Zeitschrift für ausländisches... Op. cit. p. 676.

19 Ibídem. p. 679.

20 GALANTER. Op. cit. p. 25.

${ }^{21}$ ROSENN, Keith S. O jeito na cultura jurídica brasileira. Rio de Janeiro: Renovar, 1998, p. 14.

22 GALANTER. Op. cit. pp. 22-23.

23 CAPPELLETTI. Acesso à Justiça. Op. cit. p. 24.

$24 \quad$ Ibídem. p. 27. 
As barreiras foram sintetizadas no projeto como mais pronunciadas para as pequenas causas e para os autores individuais, especialmente os pobres, e as vantagens pertencentes aos litigantes organizacionais, que usam o sistema para atenderem aos seus próprios interesses ${ }^{25}$.

Diante dessas constatações, foram sistematizadas três ondas renovatórias de acesso à Justiça, isto é, três posicionamentos, relativos ao Ocidente, que emergiram em sequência cronológica. A primeira onda renovatória envolve a assistência jurídica, a segunda envolve a representação jurídica para os interesses difusos, especialmente nas áreas de proteção ambiental e de direito do consumidor, e a terceira, denominada "enfoque de acesso à justiça", reflete a tentativa de atacar as barreiras ao acesso de modo mais articulado e compreensivo.

A primeira onda de acesso à Justiça nos países ocidentais envolveu os hipossuficientes. Na maioria dos países, o auxílio de um advogado é essencial, se não for indispensável, para a compreensão do formalismo das leis e dos tribunais. Porém, a assistência judiciária gratuita foi constada como insuficiente, porque os advogados mais experientes tenderiam a concentrar seu tempo e esforços em causas que receberiam honorários, sendo a advocacia pro bono, em geral, realizada por advogados menos experientes ${ }^{26}$.

Os sistemas em que o Estado se propõe a arcar com os honorários advocatícios caso a parte não tenha condições financeiras também não foram imunes a críticas. Na Alemanha, a proposta teve início nos anos de 1919 a 1923 e, na Inglaterra, em 1943, compensando os advogados por consultas e pela atuação em juízo. Posteriormente, foi desenvolvida por outros países, como Estados Unidos, em 1965, na França, em 1972, e na Suécia, no mesmo ano da França, seguidos, anos mais tarde, pela província de Quebec, pela Austrália e pela Holanda, além do aperfeiçoamento do sistema já existente em alguns países. O problema é que, ainda quando havia um sistema de assistência judiciária, muitos desses sistemas eram falhos, seja porque nem sempre eram os melhores escritórios de advocacia financiados pelo governo para a assistência judiciária sem ônus para os hipossuficientes, pelos melhores escritórios cobrarem mais caro e pelo governo não possuir dotação orçamento suficiente para tal; seja pela distância dos escritórios de advocacia que atuavam pro bonoem relação às áreas mais pobres da cidade;seja porque o sistema jurídico da Inglaterra, da França e da Alemanha não permitia o ajuizamento de demandas que versassem sobre uma lesão de reduzido valor aos beneficiários da justiça gratuita, para o Estado não necessitar arcar com um valor maior do que o proveito econômico

$25 \quad$ Ibídem. p. 28.

26 CAPPELLETTI. Rabels Zeitschrift für ausländisches... el i p. 682. 
da parte $^{27}$, salvo se demonstrassemque a questão não era limitada a indivíduos com a mesma situação econômica.

A segunda onda renovatória versou sobre o problema da representação dos interesses difusos. A concepção tradicional do processo civil não deixava espaço para a proteção dos direitos difusos e torna latente a preocupação com uma representatividade adequada, já que não haveria participação individual na demanda e a noção de coisa julgada necessitava ser redimensionada ${ }^{28}$. A pesquisa constatou que, embora seja a principal forma de proteção dos direitos difusos e coletivos, a atuação governamental, especialmente nos países de common law, não tem sido capaz de fazê-lo ${ }^{29}$. Apesar de haver grupos, por meio de advogados privados, tutelando o interesse coletivo, eles não são bem organizados em todos os setores, havendo uma razoável organização na área trabalhista, mas não em matéria consumerista ou para a defesa ambiental. Experiência como a das classactionsreduziria os custos estatais, mas exige especialização, experiência e recursos em áreas específicas, que nem todos os grupos possuem ${ }^{30}$. Organizações de fins não lucrativos também se constituíam para essa defesa, mas a pesquisa atentou para a responsabilidade pelos interesses que representam e a viabilidade a longo prazo.

Ainda em relação aos direitos transindividuais, cabe destacar a brilhante intervenção de Mauro Cappelletti no ano de 1974, publicado em 1976 em uma coletânea, pela Universidade de Pavia, com o título Appuntisulla tutela giurisdizional Ed iinteressi colletivi o diffusi, em que discorreu sobre a inadequação para a sociedade contemporânea, marcada por relações jurídicas e violações de massa, da tradicional dicotomia entre o público e o privado ${ }^{31}$. Defendeu Cappelletti a necessidade de adequação do processo e dos institutos processuais às novas exigências.

Por fim, a terceira onda renovatória se baseou na obtenção de reformas na assistência judiciária, com a disponibilização de advogados para os que não poderiam custear esse serviço, e com os progressos na reivindicação de direitos, tanto dos tradicionais como dos novos, com mecanismos para a tutela de direitos coletivos, especialmente dos consumidores, preservacionistas e sociais. A última onda de reformas incluiu o conjunto geral de instituições e mecanismos, pessoas e procedimentos utilizados para processar e prevenir disputas. Esse

Ibid. pp. 685-686.

CAPPELLETTI. Op. cit. p. 50.

Ibídem. p.51.

Ibídem. p. 61.

MENDES, Aluisio Gonçalves de Castro. Ações coletivas e meios de resolução coletiva de conflitos no direito comparado e nacional. 4.ed. São Paulo: RT, 2014. p. 97. 
enfoque encorajou uma ampla variedade de reformas, incluindo alterações no procedimento, mudanças na estrutura dos tribunais, o uso de pessoas leigas ou para profissionais, modificações no direito substantivo a fim de prevenir litígios e a utilização de mecanismos extrajudiciais de solução de litígios. Reconheceu, ainda, a necessidade de adequar o processo civil ao tipo de litígio.

O estudo realizado foi de tanta relevância que, posteriormente, no Brasil, outras obras se consagraram ao realizarem uma releitura do acesso à Justiça, baseadas nas conclusões de Mauro Cappelletti e Bryant Garth. Apenas a título de exemplo, já que diversas obras se debruçaram sobre este objetivo, algumas até mesmo interligando a sociologia e o direito na releitura das ondas renovatórias, uma delas foi o reestudo feito por Paulo Cezar Pinheiro Carneiro ${ }^{32}$, que trouxe quatro pilares fundamentais: acessibilidade, operosidade, utilidade e proporcionalidade.

A acessibilidade significa a existência de sujeitos de direito, capazes de estar em juízo, utilizando adequadamente o instrumental jurídico e possibilitando a efetivação de direitos individuais e coletivos. A operosidade significa que todos os envolvidos na atividade judicial devem atuar de forma que se atinja o efetivo acesso à Justiça. Por utilidade, entende-se que o processo deve assegurar o resultado da demanda, com o menor sacrifício para as partes. Na esfera da tutela coletiva é concretizado pelo alcance subjetivo da coisa julgada, que, se julgada procedente, pode beneficiar toda a coletividade, não se restringindo ao panorama típico de demandas individuais de efeitos limitados a autor e réu. Já o princípio da proporcionalidade, que se traduz pela escolha a ser feita pelo julgador quando existem dois interesses em conflito.

A outra contribuição que se destaca éa de Rodolfo de Camargo Mancuso ${ }^{33}$, que interpretou condicionantes legítimas e ilegítimas ao acesso à Justiça, ao abordar a temática da crise numérica dos processos judiciais, com as consequentes medidas adotadas no ordenamento nacional para a redução deste número e sugestões para um Judiciário renovado.

Todas essas contribuições não retiram, porém, a relevância de se revisitar o tema. Quarenta anos após o início da publicação dos resultados da pesquisa, presta-se uma singela homenagem ao grandioso estudo realizado mediante uma releitura do acesso à Justiça a partir do Brasil, à luz dos recentes estudos empíricos, julgamentos e alterações normativas efetuados no país, pontuando-se a situação no país em relação ao direito estrangeiro.

$32 \quad$ CARNEIRO. Op. cit., p. 55.

33 MANCUSO, Rodolfo de Camargo. Acesso à Justiça: Condicionantes Legítimas e Ilegítimas. São Paulo: RT, 2011. 


\section{UMA RELEITURA DA PRIMEIRA ONDA RENOVATÓRIA: ACESSO À JUSTIÇA E HIPOSSUFICIENTES.}

Quarenta anos após as constatações do Projeto Florença, a primeira onda renovatória no Brasil é marcada, em relação às custas do Poder Judiciário ${ }^{34}$, pela Lei $n^{\circ} 1.060 / 50$. A Lei ${ }^{\circ} 1.060 / 50$ foi um marco na garantia de isenção de taxas, custas e despesas processuais aos que necessitem, assegurando o exercício da cidadania e salvaguardando o direito de acesso à Justiça no país ${ }^{35}$.

À época da Lei 1.060/50, os institutos (e as instituições correlacionadas) da gratuidade de justiça e assistência jurídica gratuita não contavam com clara distinção entre $\mathrm{si}^{\mathbf{3}}$. Os Tribunais enfrentaram, e ainda enfrentam, à luz da vigência da Lei $\mathrm{n}^{\circ} 1.060 / 50$, diversos questionamentos na tentativa de tornar o sistema de gratuidade de justiça e assistência jurídica gratuita coerente. Ademais, as poucas reformas legislativas durante as décadas de sua vigência acabaram por torná-la anacrônica. O artigo 12, por exemplo, somente isenta o "pagamento de custas" sem nada mencionar quanto aos honorários advocatícios de sucumbência. Tal previsão não foi omissa à época do advento da legislação, porque era interpretada à luz do Código de Processo Civil de 1939, que não contemplava a condenação do vencido em honorários advocatícios, salvo em casos de litigância de má-fé,

34 "Custas processuais são aquilo que a parte tem de pagar para o Estado para o custeio das atividades desenvolvidas pelos próprios órgãos do Poder Judiciário (especialmente as Varas e os respectivos Cartórios ou Secretarias), segundo critério de remuneração fixado pelo Regimento de Custas do respectivo Estado ou da Justiça Federal (Lei $n^{o}$ 9.289, de 4-7-1996), conforme o caso. Estão incluidas no conceito de custas processuais, além das custas de distribuição e do preparo do recurso, o porte de remessa e retorno dos autos à instância superior, as despesas de postagem de carta citatória ou intimatória, as despesas com certidões, autenticações e registros feitos pelos cartórios judiciais". (DINAMARCO, Pedro da Silva. Custas, Despesas, Honorários e Danos Processuais na Nova Lei da Ação Civil Pública. In: GOZZOLI, María Clara, CIANCI, Mirna, CALMON, Petrônio, QUARTIERI, Rita. Em Defesa de um Novo Sistema de Processos Coletivos. Estudos em Homenagem a Ada Pellegrini Grinover. São Paulo: Saraiva. 2010, p. 474).

35 NUNES, Rizzatto. "A assistência judiciária e a assistência jurídica: uma confusão a ser solvida". Saraivajur. São Paulo: Saraiva, 2004. pp. 1-5

36 A gratuidade de justiça se refere na garantia de isenção de taxas, custas e despesas processuais aos que necessitem, enquanto a assistência judiciária significa o serviço gratuito de representação em juízo, suprindo a capacidade postulatória e a assistência jurídica é uma expressão mais ampla, que compreende tanto a assistência judiciária, como a consultoria e a orientação jurídica, inclusive extrajudicial, em geral. (NERY JR., Nelson. Princípios do Processo Civil na Constituição Federal. 5. ed. São Paulo: RT, 2005, p. 77). 
dolo ou culpa da parte. ${ }^{37}$ Com o advento do Código de Processo Civil de 1973, acabou por restar omissa a previsão dos honorários sucumbenciais.

Pelo escopo legal da Lei $\mathrm{n}^{\circ} 1.060 / 50$, para concessão da gratuidade de justiça, basta a mera declaração, feita pelo próprio interessado, de que a sua situação econômica não permite vir a juízo sem prejuízo da sua manutenção ou de sua família, que haveria uma presunção iuris tantum de veracidade, suficiente à concessão do benefício legal. Contudo, a Constituição de 1988 passou a dispor, em seu artigo $5^{\circ}$, inciso LXXIV, que a assistência judicial e gratuita será concedida pelo Estado aos que comprovarem a hipossuficiência de recursos.

Diante dessa previsão, a jurisprudência tornou-se divergente, ora mantendo a concessão por mera declaração de pobreza, que pode ser infirmada por prova em contrário ${ }^{38}$, ora afirmando que a previsão da Lei $\mathrm{n}^{\circ}$ 1.060/50 não teria sido recepcionada pela Constituição Federal, cabendo a quem dela pretende se beneficiar demonstrar que não possui condições de arcar com os custos do processo sem prejuízo de sua subsistência ou de sua família ${ }^{39}$. No caso, porém, de pessoa jurídica, não há dúvida de que o benefício poderá ser concedido, desde que comprovem não possuir rendimentos para arcar com as custas da demanda ${ }^{40}$.

Porém, os artigos $2^{\circ}, 3^{\circ}, 4^{\circ}, 6^{\circ}, 7^{\circ}, 11,12$ e 17 dessa lei serão expressamente revogados pelo novo Código de Processo Civil, nos termos do artigo 1.072 do novel diploma, que entrará em vigor em 17 de março de 2016. O novo diploma trata do tema em seus artigos 98 a 102.

37 "Por isso, ao não incluir expressamente o termo "honorários" na redação original do art. 12 da Lei $n^{\circ}$ 1.060/1950, não pretendeu o legislador excluir os honorários sucumbenciais do âmbito de incidência da gratuidade de justiça; ele não incluiu, simplesmente, porque não era necessário incluir". (SILVA, Franklin Roger Alves; ESTEVES, Diogo. Princípios Institucionais da Defensoria Pública: de acordo com a EC 74/2013 (Defensoria Pública da União). Rio de Janeiro: Forense, 2014. p. 208).

38 Nesse sentido: STJ. ROMS 200801458635. Rel. Min. Benedito Gonçalves. Primeira Turma. DJ: 03/12/2008, STJ. AGA 200702067528. Rel. Min. Fernando Gonçalves. Quarta Turma. DJ: 17/11/2008 e STJ. AGA 200800208427. Rel. Min. Maria Thereza de Assis Moura. Sexta Turma. DJ: 16/06/2008.

39 Nesse sentido: STJ. AGA 200502116381. Rel. Juiz Federal Convocado Carlos Fernando Mathias. Quarta Turma. DJ: 15/09/2008 e STJ. REsp. 200500482263. Rel. Min. Jorge Scartezzini. Quarta Turma. DJ: 14/11/2005.

40 Nesse sentido: STJ. REsp 642.288/RS. Rel. Min. Eliana Calmon. Segunda Turma. DJ: 15/09/2005 e STJ. ADRESP 201102824955. Rel. Min. Paulo de Tarso Sanseverino. Terceira Turma. DJ: 05/03/2013. 
Com a entrada em vigor do novo Código de Processo Civil ${ }^{41}$, vale citar que a gratuidade alcançaránão apenas as pessoas físicas, como também as pessoas jurídicas, nacionais ou estrangeiras, com insuficiência de recursos para pagar as custas, as despesas processuais e os honorários advocatícios. Porém, enquanto para a pessoa física o Código $3^{\circ}$ foi bastante categórico em adotar a teoria presumicionista para fins da gratuidade de justiça, para a pessoa jurídica, é necessária a comprovação de não possuir rendimentos para arcar com as custas da demanda ${ }^{42}$. Além disso, o novo diploma prevê a gratuidade de emolumentos pelos atos dos notários e registradores e a forma de sua impugnação dependerá do momento em que tiver sido requerida nos autos.

A revogação da gratuidade de justiça possui regramento expresso no art. 102, que dispõe que, revogada a gratuidade,a parte deverá efetuar o recolhimento de todas as despesas de cujo adiantamento foi dispensada, inclusive as relativas ao recurso interposto, se houver, no prazo fixado pelo juiz, sem prejuízo de aplicação das sanções previstas em lei. Caso não seja efetuado o recolhimento, o processo será extinto sem resolução de mérito, tratando-se do autor e, nos demais casos, não poderá ser deferida a realização de qualquer ato ou diligência requerida pela parte enquanto não efetuado o depósito.

No direito estrangeiro, há, também, reformas mais recentes estão relacionadas à tentativa de redução das custas processuais e de alcançar maior celeridade ao processo $^{43}$. Qualquer melhoria subsequente do acesso dos cidadãos é um efeito colateral, positivo, mas secundário ${ }^{44}$. Todavia, essas reformas não representaram um desejo altruístico de valorizar a cidadania e nem uma crise de confiança no Poder Judiciário, mas apenas uma tentativa de reduzir os custos dos serviços jurídicos ${ }^{45}$.

41 Sobre o tem, remete-se a: MENDES, Aluisio Gonçalves de Castro, SILVA, Larissa Clare Pochmann da, BARRETO, Susana Cadore Nunes. A Gratuidade de Justiça e a Assistência Jurídica Gratuita no novo Código de Processo Civil. Artigo no prelo.

42 Nesse sentido: Enunciado de Súmula n 481 do STJ: "Faz jus ao benefício da justiça gratuita a pessoa jurídica com ou sem fins lucrativos que demonstrar sua impossibilidade de arcar com os encargos processuais".

43 ZUCKERMAN, Adrian A. S. "A Reform of Civil Procedure - Rationing Procedure Rather than Access to Justice". Journal of Law and Society. Utah: Law and Society, 22, n. 155, 1995, p. 1-26. Disponível em http://adrianzuckerman.co.uk/files/File/Economy.dr7\%20 PDF\%20test.pdf. [Acesso em 21 dez. 2014].

44 ECONOMIDES, Kim. Lendo as ondas do "Movimento de Acesso à Justiça": epistemologia versus metodologia?Trad. Paulo Martins Garchet. In: PANDOLFI, Dulce Chaves, CARVALHO, José Murilo de, CARNEIRO, Leandro Piquet, GRYNSZPAN, Mario. Cidadania, Justiça e Violência. Rio de Janeiro: Fundação Getúlio Vargas Editora, 1999. p. 70. Ibídem. 
Vários países fizeram reformas para reduzir os custos. Além do célebre relatório de Lord Jackson, na Inglaterra, em 2002 a Bélgica reformou suas regras para prever a sucumbência e, em 2008, foi a vez de Portugal realizar alterações, preocupando-se em coibir demandas protelatórias e prever o princípio da causalidade para as custas ${ }^{46}$. Contudo, a alteração mais recente nas custas processuais ocorreu no Reino Unido em abril de $2013^{47}$, trazendo um novo regime de custas fixas, além de limitar os honorários de sucumbência a $25 \%$ dos danos, excluindo danos futuros; elevar os danos morais em $10 \%$ e estabelecer sanções aos réus que protelam as demandas, tentando incentivar acordos no curso do processo.

Em relação aos honorários advocatícios, cabe destacar que o Brasil dispõe de defensores públicos tanto na Justiça Estadual como na Justiça Federal, mas ainda em quantidade insuficiente em muitos estados da federação, o que não pôs fim à atuação de advogados dativos, atuação essa já criticada no Projeto Florença há quarenta anos.

Essas dificuldades ainda hoje enfrentadas pela Defensoria Pública restaram retratadas na Ação Direta de Inconstitucionalidade no 3.943-1, protocolada em 16 de agosto de 2007, pela Associação Nacional dos Membros do Ministério Público, questionando a previsão da Lei no 11.448, de 15 de janeiro de 2007, que acrescentou a previsão de legitimidade da Defensoria Pública para o ajuizamento de ações coletivas, inserindo a instituição no rol do art. $5^{\circ}$ da Lei no 7.347/85.

A liminar na ADIn não foi concedida, mas o parecer do Ministério Público Federal, proferido em 21 de fevereiro de $2008^{48}$, foi no sentido da inconstitucionalidade do dispositivo, que trouxe a previsão expressa de legitimidade da Defensoria Pública ao ordenamento jurídico brasileiro.As razões do parecer, preliminarmente, reconheceram a pertinência temática da Associação Nacional do Ministério Público a provocar o Supremo Tribunal Federal sobre o tema. No mérito, além de discussões de tutela coletiva, que serão analisadas somente quando da exposição sobre a segunda onda renovatória, destacaram que as Defensorias ainda vivem uma realidade de dificuldades na alocação de recursos humanos, financeiros e logísticos para a criação, para a instalação e para o

46 HODGES, Christopher, VOGENAUER, Stefan, TULIBACKA, Magdalena. Costs and Funding of Civil Litigation: A Comparative Study. Oxford; Portland: Oregon, 2010. pp. 10-11.

47 As alterações nas custas processuais no Reino Unido serão abordadas na terceira onda renovatória e podem ser obtidas em: https://www.justice.gov.uk/civil-justice-reforms. [Acesso em 20 dez. 2014].

48 O referido parecer está disponível no endereço eletrônico da Associação Nacional dos Membros do Ministério Público, em http://www.conamp.org.br/Lists/Proposies\%20 Legislativas/DispForm.aspx?ID=73. [Acesso em 5 dez. 2014]. 
funcionamento em diversos estados. Dessa forma, a atribuição de legitimidade para o processo coletivo apenas agravaria mais esta realidade.

Somente em 2015, após a Emenda Constitucional n 80/2014 acrescentar à Constituição Brasileira a legitimidade da Defensoria Pública para as ações coletivas, o Supremo Tribunal Federal bem procedeu ao analisar a ação e reiterar a legitimidade da Defensoria Pública para as ações coletivas, mas o julgamento não foi capaz de despertar a atenção para a necessidade da ampliação donúmero de defensores públicos no país, para o fortalecimento da instituição e o aprimoramento do acesso à justiça aos hipossuficientes.

Destaque-se, ainda, que, ainda mais recente, no ano de 2012, ao apreciar as Ações Diretas de Inconstitucionalidade no 3892 e 4270, o Supremo Tribunal Federal declarou a inconstitucionalidade de normas do Estado de Santa Catarina que dispõem sobre a defensoria dativa e a assistência judiciária gratuita. O estado não possuía defensoria pública e a população hipossuficiente recebe prestação jurídica gratuita por meio de advogados dativos indicados pela seccional catarinense da Ordem dos Advogados do Brasil (OAB-SC).A Corte decidiu que essa situação no estado deveria durar por mais um ano, quando os dispositivos contestados (artigo 104 da Constituição de Santa Catarina e Lei Complementar Estadual 155/97) perderiam eficácia no ordenamento jurídico.

Atualmente, o estado de Santa Catarina realizou concurso e já possui alguns defensores públicos, mas em número ainda insuficiente para atendimento em todo o estado, subsistindo a atuação de defensores dativos, em uma busca dos novos defensores para ampliação do quantitativo de profissionais aprovados por concurso público para a carreira.

Em 2014, com o advento da Emenda Constitucional 80, a Constituição passou a dispor, em seu artigo $98, \$ 1^{\circ}$ que, no prazo de 8 (oito) anos, a União, os Estados e o Distrito Federal deverão contar com defensores públicos em todas as unidades jurisdicionais, o que significa que apenas em 2022 deverá haver defensor público em todas as comarcas e seções judiciárias, facilitando o acesso à Justiça dos hipossuficientes no Brasil. Essa meta, porém, enfrenta diversos desafios orçamentários no país.

O modelo de assistência jurídica pela Defensoria Pública e pelos defensores dativos é complementado, ainda, pela atuação dos escritórios modelo das faculdades de Direito, composto por um professor orientador, advogados e estagiários, que são alunos da própria faculdade, a partir do sétimo período, com carteira de estagiário da Ordem dos Advogados do Brasil -OAB-, salvo nos casos dos impedimentos legais, que lá aprendem, orientados e supervisionados por profissionais habilitados, o exercício da advocacia. 
A assistência jurídica gratuita varia, hoje, em diversos países. Habitualmente, os advogados atendem a categorias particulares de clientes (os grandes escritórios de advocacia têm entre seus principais clientes os setores corporativos), enquanto os que não possuem condições de arcar com um advogado procuram a assistência judiciária gratuita, mas os setores de disponibilidade da assistência gratuita acabam sendo definidas em função do serviço jurídico que o Estado deseja incentivar ${ }^{49}$. Por exemplo, quando o Estado quer incentivar a solução extrajudicial de conflitos, disponibiliza assistência judiciária gratuita também nessa área.

No Canadáé atribuição de cada província assegurar o patrocínio gratuito, mediante a remuneração, pelas províncias, do advogado, para que atenda gratuitamente os hipossuficientes, judicial e extrajudicialmente, com assistência presencial ou orientação por telefone. Nesse sentido, por exemplo, a Legal AidOntário é responsável por prover a assistência judiciária em todos os setores para os residentes em Ontário; a Legal Services Societypara os residentes na província de British Columbia e a Commissiondes Services Juridiques para os residentes na província de Quebec. Cada uma dessas instituições fornece informações a advogados, para como prestarem a assistência gratuita e serem remunerados pela província em que atuam, bem como aos hipossuficientes, sobre endereços e áreas de atuação. No caso da Legal Aid Ontário, o patrocínio abrange as áreas criminal, violência doméstica, direito de família, imigração e refugiados, civil, direito imobiliário, previdenciária, assistência a estrangeiros e aborígenes. Atuações na defesa de direitos transindividuais não são realizadas pelos advogados remunerados pela província que, segundo dados de 2013/2014, atuaram em 28.783 casos em matéria de família; 13.355 casos criminais e 2.390 casos de imigrantes e refugiados ${ }^{50}$.

Nos Estados Unidos, a assistência jurídica gratuita também é realizada por advogados, remunerados pelo Estado, com receitas de um fundo a nível nacional. Para se beneficiar do programa, é preciso que a renda, considerando uma família de quatro pessoas, seja igual ou inferior a US $\$ 25.000$ por ano, o que o governo estima abranger mais de 50 milhões de norte-americanos e 13 milhões de crianças. O programa possui um endereço eletrônico oficial ${ }^{51}$, indicando os escritórios ou grupos de advogados que prestam a assistência judiciária gratuita

SCHUYT, Keeset alii. "The Road to Law". In: BLEGVAD, B.M., CAMPBEL, C.M., SCHUYT, C.J. European Yearbook in Law and Sociology. The Hague: Martinus Nijhoff, 1977. p. 111. Informação disponível no Legal Aid Ontario, em http://www.legalaid.on.ca/en/getting/ default.asp. [Acesso em 23 dez. 2014].

51 Disponível em http://legalaid.uslegal.com/. [Acesso em 23 dez. 2014]. 
em cada estado, sendo que, na maioria dos estados, são apenas um único ou dois escritórios de advocacia ou grupos de advogado. Complementando o sistema norte-americano, há, ainda, as clínicas das faculdades de Direito, que prestam assistência gratuita aos hipossuficientes e escritórios de advocacia privada que possuem uma cota de atuação pro Bono em relação ao número de clientes que arcam com os honorários advocatícios.

Já nos países da União Europeia, há assistência jurídica gratuita é prevista aos hipossuficientes no art. 47, $\$ 3^{\circ}$ da Carta de Direitos Fundamentais da União Europeia e regulamentado, desde 27 de janeiro de 2003, pela Diretiva 2002/8/ $\mathrm{CE}$, para estabelecer regras mínimas de assistência jurídica transfronteiriça para os países membros. Na Alemanha ${ }^{52}$, é diferenciada a assistência judiciária para assessoria e para atuação em tribunais, ambas feitas por advogados, remunerados pelo requerente, no que tiver condições de contribuir, e remunerado pelo Estado, no restante dos honorários. O requerente procura o sistema no tribunal, mesmo que seja para aconselhamento, e deve levar seu contracheque ou declaração de renda para comprovar que é beneficiário do sistema. Pode lhe ser cobrada uma taxa de dez euros pelo uso do sistema, que será dispensada no caso concreto se não houver condições de sequer arcar com ela. O sistema de aconselhamento e, se necessária, a atuação judicial ocorre nos casos cíveis, como os que envolvam direito do trabalho, direito administrativo e direitos sociais. Já no caso de infrações penais ou administrativas, esses advogados atuam apenas para aconselhamento, sem atuação em juízo. Não há assistência gratuita para questões tributárias. Em se tratando de estrangeiros, o aconselhamento só é feito se a questão possuir conexão com as leis alemãs.

$\mathrm{Na}$ Inglaterra e nos Países de Gales, também se distingue o aconselhamento inicial da atuação judicial, bem como é diferenciada a atuação em processos que versem sobre direito de família. Nos casos mais complexos, que demandam maiores honorários, o financiamento da assistência judiciária é privado, sendo que o beneficiário paga uma taxa por isso. Nos demais casos, de financiamento estatal, qualquer pessoa física, independente da nacionalidade, pode se beneficiar, desde que não tenham renda mensal bruta superior a $£ 2.288$ e não tenham recebido benefício do governo. Se receberem entre $£ 3.000$ e $£ 8.000$, será oferecido apenas um financiamento aos seus custos para o acesso à Justiça. $\mathrm{O}$ atendimento não está disponível para difamação, conflitos de vizinhança, direito imobiliário, elaboração de testamento, direito da concorrência, casos de negligência ou de direito empresarial, mas, excepcionalmente, nos casos de exclusão,

52 EUROPEAN JUDICIAL NETWORK IN CIVIL AND COMMERCIAL MATTERS - Germany. Disponível em http://ec.europa.eu/civiljustice/legal_aid/legal_aid_ger_en.htm. [Acesso em 23 dez. 2014]. 
pode ser concedido financiamento, mediante a análise do caso concreto. A lista dos advogados que atuam na assistência judiciária é disponibilizada através de um sítio eletrônico ${ }^{53}$ e deve ser procurado o profissional tendo em mãos contracheque e extratos bancários, para avaliação. Fora da Inglaterra e dos Países de Gales, a assistência no Reino Unido ${ }^{54}$ se limita ao Tribunal de Justiça da União Europeia.

Em termos estatísticos, os dados foram divulgados em 2014, mas com base em 2012 e envolvem a Itália e a França: na Itália, a assistência judiciária abrangeu 320 casos a cada cem mil habitantes e, na França, 1.396 casos a cada cem mil habitantes ${ }^{55}$. A França concede assistência judiciária tanto para consulta, como para atuação em juízo, e os beneficiários também possuem auxílio em relação às custas judiciais, e esse benefício pode ser total ou parcial, dependendo da situação econômica do requerente. Para ser beneficiário, é preciso que a renda média no ano anterior não ultrapasse um limite fixado anualmente por lei, aí não se incluindo bônus recebidos e prestações sociais. Além disso, é preciso ser cidadão francês, da União Europeia, ou ter domicílio no território francês para fazer jus ao benefício ${ }^{56}$.

Já na Itália a assistência jurídica é para demandas civis e não contenciosas e seus beneficiários não arcam, também, com as custas processuais. Há uma taxa a ser paga para usufruir dela, que vaia conforme o valor da causa e pode ser concedida ede forma total ou parcial. Qualquer pessoa com um rendimento não superior a $€ 9.269,22$, conforme mostra a sua mais recente declaração de rendimentos, tem direito ao apoio judiciário. O limite de renda é ajustado a cada dois anos, por ordem do Ministério da Justiça para ter em conta as variações no índice de preços ao consumidor ${ }^{57}$.

Dessa forma, pode-se perceber que, em que pese o avanço nos sistemas de assistência aos hipossuficientes, hoje, quarenta anos após o início da divulgação

53 O endereço pode ser acessado em http://www.justask.org.uk/. [Acesso em 23 dez. 2014].

54 EUROPEAN JUDICIAL NETWORK IN CIVIL AND COMMERCIAL MATTERS - England and Wales. Disponível em http://ec.europa.eu/civiljustice/legal_aid/legal_aid_ eng_en.htm. [Acesso em 23 dez. 2014].

55 EUROPEAN COMISSION FOR THE EFFICIENCY OF JUSTICE (CEPEJ). Study on the functioning of judicial systems in the EU Member States: facts and figures from the CEPEJ 2012-2014 evalution exercise. Estrasburgo: CEPEJ, 2014. p. 112.

56 EUROPEAN JUDICIAL NETWORK IN CIVIL AND COMMERCIAL MATTERS France. Disponível em http://ec.europa.eu/civiljustice/legal_aid/legal_aid_fra_en.htm. [Acesso em 26 dez. 2014].

57 EUROPEAN JUDICIAL NETWORK IN CIVIL AND COMMERCIAL MATTERS Italy. Disponível em http://ec.europa.eu/civiljustice/legal_aid/legal_aid_ita_en.htm. Acesso em 26 dez. 2014. 
das pesquisas do Projeto Florença, em muitos países, inclusive no Brasil, ela ainda pode ser aprimorada, reduzindo os entraves para o acesso à Justiça, de forma a que todos os hipossuficientes possam ter fácil acesso à assistência judiciária gratuita e de qualidade.

\section{UMA RELEITURA DA SEGUNDA ONDA RENOVATÓRIA: A TUTEla COletiva E A SOluÇÃO COLETIVA DE CONFLITOS.}

Uma releitura da segunda onda renovatória na atualidade abrange não apenas as ações coletivas, como também os mecanismos de solução coletiva de conflitos. Atualmente, é inegável a relevância dos direitos difusos, coletivos e individuais homogêneos, mas muitos pontos ainda desafiam a tutela coletiva.

No Brasil, a coisa julgada está disciplinada no art. 103 do $\mathrm{CDC}^{58}$, mas o ponto que merece destaque é o julgado de outubro de 2011 da Corte Especial do Superior Tribunal de Justiça,quando se afastou a limitação territorial teratológica dos efeitos da coisa julgada prevista no artigo 16 da Lei $n^{\circ} 7.347 / 85$ (Lei da Ação Civil Pública), apresentando um tratamento mais adequado ao tema. A legitimidade, porém, ainda continua cercada de controvérsia, especialmente a legitimidade ativa do indivíduo para a ação coletiva no cenário brasileiro.

$58 \quad$ BRASIL. Código de Defesa do Consumidor. Brasília: Planalto, 1990.

ART. 103.-"Nas ações coletivas de que trata este código, a sentença fará coisa julgada:

I - erga omnes, exceto se o pedido for julgado improcedente por insuficiência de provas, hipótese em que qualquer legitimado poderá intentar outra ação, com idêntico fundamento valendo-se de nova prova, na hipótese do inciso I do parágrafo único do art. 81; II - ultra partes, mas limitadamente ao grupo, categoria ou classe, salvo improcedência por insuficiência de provas, nos termos do inciso anterior, quando se tratar da hipótese prevista no inciso II do parágrafo único do art. 81;

III - erga omnes, apenas no caso de procedência do pedido, para beneficiar todas as vítimas e seus sucessores, na hipótese do inciso III do parágrafo único do art. 81 .

$\mathbb{S} 1^{\circ}$ Os efeitos da coisa julgada previstos nos incisos I e II não prejudicarão interesses e direitos individuais dos integrantes da coletividade, do grupo, categoria ou classe.

$\mathbb{\$} 2^{\circ} \mathrm{Na}$ hipótese prevista no inciso III, em caso de improcedência do pedido, os interessados que não tiverem intervindo no processo como litisconsortes poderão propor ação de indenização a título individual.

$\mathbb{S} 3^{\circ}$ Os efeitos da coisa julgada de que cuida o art. 16, combinado com o art. 13 da Lei $\mathrm{n}^{\circ}$ 7.347, de 24 de julho de 1985, não prejudicarão as ações de indenização por danos pessoalmente sofridos, propostas individualmente ou na forma prevista neste código, mas, se procedente o pedido, beneficiarão as vítimas e seus sucessores, que poderão proceder à liquidação e à execução, nos termos dos arts. 96 a 99.

$\mathbb{\$} 4^{\circ}$ Aplica-se o disposto no parágrafo anterior à sentença penal condenatória”. 
São legitimados, no setor público, o Ministério Público (art. 5, I, Lei 7.347/85); a Defensoria Pública (art. 5º II, da mesma lei); a União, dos Estados, o Distrito Federal e dos Municípios (art. 5, III) e a autarquia, da empresa pública, da fundação ou da sociedade de economia mista (art. $5^{\circ}$, IV, da Lei ${ }^{\circ}$ 7.347/85). A atuação do Ministério Público tem fundamento constitucional, já que o art. 127, caput, da Constituição $0^{59}$ assegura-lhe a defesa da ordem jurídica, da ordem democrática e dos interesses sociais e individuais indisponíveis; o art. 129 enumera suas atribuições institucionais, sendo que o art. 129, III, afirma apenas a possibilidade da defesa de direitos difusos e coletivos, sem mencionar os individuais homogêneos.Dessa forma, surgiu a discussão se o Ministério Público seria legitimado para a tutela de direitos individuais homogêneos. Prevalece que é admitida a legitimidade ativa do Ministério Público para direitos individuais homogêneos em que seja identificada a relevância social do bem jurídico em litígio ${ }^{60}$.Ainda que se considerem o possível número de ações em que o Ministério Público não foi considerado legitimado por se tratar de direitos individuais homogêneos e a dificuldade da precisão de dados sobre o número de ações civis públicas no Brasil hoje, o Ministério Público é o legitimado ativo mais bem sucedido na tutela coletiva. As previsões de Mauro Cappelletti, em relação à atuação do Ministério Público nas ações coletivas, ao menos no Brasil, não se confirmaram, diante do desenvolvimento e da atuação prática da instituição: o dia a dia vem revelando uma atuação corajosa e aguerrida da instituição, com a atuação mais relevante em termos de direitos transindividuais ${ }^{61}$, mostrando-se ativa até mesmo em face do Poder Público.

Já a Defensoria Pública, segundo concepção majoritária com atuação restrita a um grupo de pessoas, classe ou categoria que a procura e invoca a condição de hipossuficiente ${ }^{62}$, teve sua legitimidade para a tutela coletiva inicialmente prevista pela Lei $\mathrm{n}^{\circ} 11.448$, de 15 de janeiro de 2007, que a inseriu no rol do art. $5^{\circ}$ da Lei $n^{\circ} 7.347 / 85$. Foi protocolada a Ação Direta de Inconstitucionalidade $n^{\circ}$ 3.943-1 em face de tal previsão, que deve perder o objeto com o advento da EC 80/2014, que alterou a redação do art. 134, caput, da Constituição Federal, não deixando dúvida quanto à possibilidade da Defensoria atuar na tutela coletiva, esperando-se que seja cada vez mais aguerrida a atuação do setor público no Brasil.

$59 \quad$ BRASIL. Constituição Federal. Brasília: Planalto, 1988.

60 MENDES. Op. cit. p. 259.

$61 \quad$ Ibídem. p. 261.

62 MANCUSO, Rodolfo de Camargo. Ação Civil Pública em defesa do meio ambiente, do patrimônio cultural e dos consumidores - Lei 7.347/1985 e legislação complementar. 11.ed. São Paulo: RT, 2009. pp. 145-147. 
Por outro lado, as associações brasileiras não são tão atuantes como as alemãs. $\mathrm{Na}$ Alemanha, as associações são as legitimadas ativas para o processo coletivo, sendo as principais responsáveis por tutelar os direitos transindividuais, mas em matérias restritas como no direito da concorrência e no direito do consumidor. As associações possuem legitimidade para pleitear uma tutela que previna ou faça cessar a lesão, mas não para pleitear medida ressarcitória ${ }^{63}$, que só pode ser obtida em demandas individuais.

Apenas uma única associação no país, a Wettbewerbszentrale, em 2004, ajuizou 454 ações coletivas; em 2005, 688 e, em 2006, 600 ações coletivas, representando a maior parte das ações coletivas ajuizadas no país nesse ano. A referida associação obteve um percentual de $85 \%$ de ações coletivas bem-sucedidas $^{64}$. Tais dados, porém, não significam um cenário de atuação intensa de uma associação específica. No período de 1970 a 2001, foram 3.500 as ações coletivas ajuizadas pelas associações no país ${ }^{65}$.

Em contrapartida, as associações brasileiras, possuem uma atuação cada vez mais crescente. É certo que a inexistência de dados oficiais sobre as ações coletivas dificulta traçar o perfil das associações e quantificar suas atuações, mas, tal como destacado por Mauro Cappelletti há quarenta anos, no Brasil permanece, ainda, a falta de uma cultura associativa e o preparo para a atuação na defesa de direitos transindividuais.

Ainda quanto à legitimidade, no Brasil, a exclusão da legitimidade do indivíduo para a ação civil pública diz respeito a um possível uso político-eleitoral de demandas coletivas, advindas da experiência com a ação popular ${ }^{66}$.Lembra Eurico Ferraresi que o fundamento seria que o "brasileiro não está preparado para utilizar judicialmente as ações coletivas"; e, caso fosse possível, poder-se-ia ter uma explosão de demandas, "sem relevância, o que retiraria força e credibilidade desse instrumento" ${ }^{67}$. Complementando esse pensamento, afirma-se que o uso indiscriminado desse instrumento pelas pessoas físicas poderia gerar "inúmeras

$63 \quad \mathrm{KOCH}$, Harald. "Non-Class Group Litigation Under EU and German Law”. Duke Journal of Comparative E International Law. Carolina do Norte: Duke Law School, 2001, vol. 11. p. 360.

64 BAETGE, Dietmar. Class Actions, Group Litigation and Other Forms of Collective Litigation, p. 17. Disponível em: http://www.law.stanford.edu/display/images/dynamic/ events_media/Germany_National_Report.pdf. [Acesso em 15 dez. 2014]. Ibídem. p. 30.

66 GRINOVER, Ada Pellegrini et alii. Código Brasileiro de Defesa do Consumidor. 9. ed. Rio de Janeiro: Forense Universitária, 2007. p. 807.

67 FERRARESI, Eurico. Ação popular, Ação Civil Pública e Mandado de Segurança Coletivo. Instrumentos Processuais Coletivos. Rio de Janeiro: Forense, 2009. p. 137. 
repercussões perniciosas que, mesmo nos casos de improcedência, jamais poderão ser reparadas" ${ }^{68}$.Além desses argumentos, prossegue-se no sentido de que há despreparo cultural, político e, até mesmo, intelectivo-educacional do cidadão brasileiro comum para o exercício individual de tal $^{69}$.

Todavia, não se considera que atribuir a legitimidade ao indivíduo70é garantir-lhe o acesso à Justiça para a tutela dos direitos coletivos em sentido amplo, destacar que o indivíduo pode atuar -e não que necessariamente deva atuarsem ter de presenciar lesões ou ameaças de lesão a direitos e ter de aguardar como mero espectador.

Cabe destacar que as custas processuais são um entrave para o acesso à Justiça seja no cenário individual seja no cenário coletivo, mas não seriam uma barreira para a atuação do indivíduo no Brasil. O indivíduo que desejar atuar também não precisa ter uma condição financeira privilegiada para arcar com os custos de um advogado. Além dos honorários poderem ser pagos por toda a classe, o que pode tornar os honorários até em valores inferiores no cenário coletivo do que do ponto de vista individual, um advogado que patrocina interesses na tutela coletiva, muito além de uma boa remuneração na causa, adquire, ainda, grande prestígio social.

Eventual atuação de má-fé não se restringe ao cenário de atuação apenas do indivíduo, podendo ocorrer com outros legitimados, especialmente as associações. Nesse caso, além de se cogitar da possibilidade de se aplicar à previsão de condenação das associações que atuarem de má-fé em custas processuais também aos indivíduos que ajuizarem ações coletivas de má-fé, a relevante atuação do Ministério Público como fiscal da lei também reduziria essa possibilidade.

Também merece crítica o sistema de processo de conhecimento coletivo e execução, em se tratando de direitos individuais homogêneos, prioritariamente individual, com a ideia de que a sentença será sempre genérica, sem se cogitar de um sistema também de execução coletiva. Nem sempre haverá a ausência de determinação dos beneficiários da sentença e liquidez da condenação. Pode-se pensar, por exemplo, em sentenças condenatórias de obrigações de fazer, não

68 PUOLI, José Carlos Baptisti. Comentários à lei de ação civil pública -art. $1^{\circ}$. In: COSTA, Susana Henriques (coord.) Comentários à lei da ação civil pública e lei da ação popular. São Paulo: Quartier Latin, 2006. p. 333.

69 Ibídem.

70 As conclusões aqui trazidas sobre o tema são desenvolvidas em: MENDES, Aluisio Gonçalves de Castro, SILVA, Larissa Clare Pochmann da. "A Legitimidade Ativa do Indivíduo nas Ações Coletivas". Revista de Processo. São Paulo: RT, ano 38, vol. 220, jun. 2013. p. 33-46. 
fazer ou entrega de coisa, bem como de pagar quantia certa, nas quais o objeto da obrigação já esteja determinado ${ }^{71}$, em que não haveria uma condenação genérica e que seria possível e até recomendável uma execução de caráter coletivo.

O novo Código de Processo Civil traz novas perspectivas em relação à segunda onda renovatória, inaugurando no ordenamento jurídico brasileiro um novo instrumento para a solução coletiva de conflitos: o incidente de resolução de demandas repetitivas. Sem um instrumento para solucionar as demandas de massa que se acumulam na primeira instância e mantendo a sistemática hoje existente dos recursos repetitivos, o novo diploma inaugura um tratamento coletivo para demandas massificadas, a ser julgado pelos tribunais.

$\mathrm{O}$ incidente de resolução de demandas repetitivas ${ }^{72}$ pressupõe o risco de ofensa à isonomia e à segurança jurídica, diante da efetiva repetição de processos que contenham controvérsia sobre questão unicamente de direito, material ou processual. Assim, havendo uma questão comum de direito, que possa gerar efetiva repetição de processos, de ofício ou a requerimento das partes, da Defensoria Pública ou do Ministério Público, poderá ser suscitado o incidente de resolução de demandas repetitivas, a ser apreciado, em termos de admissibilidade e de mérito, pelo tribunal de segundo grau, com a suspensão de todos os processos, na área do tribunal, que dependam da resolução da questão de direito. $\mathrm{O}$ novo $\mathrm{CPC}$ estabelece que a instauração e o julgamento serão sucedidos da mais ampla e específica divulgação e publicidade, por meio de registro eletrônico no Conselho Nacional de Justiça, bem como que os tribunais promoverão a formação e a atualização de banco eletrônico de dados sobre questão de direito submetida ao incidente, comunicando, imediatamente, ao CNJ, para inclusão no cadastro. O julgamento do incidente poderá ser impugnado diretamente mediante recurso especial ou extraordinário. Em seguida, os órgãos judiciais vinculados ao tribunal prolator da decisão aplicarão a tese jurídica transitada em julgado aos processos individuais. Em caso de inobservância da tese, caberá reclamação.

Em contrapartida à realidade brasileira, no cenário estrangeiro, cabe destacar que, nos Estados Unidos ${ }^{73}$, as ações coletivas passaram por transformações. Nas

$71 \quad$ MENDES. Op. cit. p. 288.

$72 \quad$ Ibídem. pp. 297-305.

73 Para um estudo detalhado das ações coletivas no direito norte-americano, remete-se a MENDES, Aluisio Gonçalves de Castro. Ações coletivas e meios de resolução coletiva de conflitos no direito comparado e nacional. 4.ed. São Paulo: RT, 2014 e MENDES, Aluisio Gonçalves de Castro. Ações coletivas no direito comparado. XX Congreso Mexicano de Derecho Procesal Durango, 26 a 28 de novembro de 2014. Trabalho no prelo. 
décadas de 1960 e 1970, nos Estados Unidos as ações coletivas eram marcadas pela temática da defesa dos direitos sociais ${ }^{74-75}$. Já na década de 90 , as ações coletivas nos Estados Unidos voltaram-se a matérias relacionadas ao direito do consumidor e à proteção ambiental ${ }^{76}$.

O maior desafio das ações de classe nos Estados Unidos hoje no caso de ações coletivas para ressarcimento de danos é demonstrar a adequação da representatividade. Muitas ações de classe não são certificadas porque seus representantes - na maioria dos casos, indivíduos- não conseguem averiguar a situação, deixando de observar na ação proposta todos os pedidos de muitos afetados pelo dano ${ }^{77}$. Para isso, muitos advogados, seguindo uma instrução ética das associações de advogados norte-americanas ${ }^{78}$, reúnem-se antes da propositura da ação com os indivíduos que figurarão como representantes da classe, para reverem as reivindicações e confirmar se não usaram suas posições de demandantes para conseguirem uma solução apenas para si em detrimento da classe. Os demandantes nomeados devem expressar a disposição de participar de todas as exigências feitas pela classe. Eles também devem entender a importância da relação advogado-cliente e a necessidade de confidencialidade em relação às matérias privilegiadas.Além disso, o financiamento ao litígio tem se revelado uma preocupação recente, relevante, por ser capaz de desequilibrar a relação processual, mas ainda sem resposta ${ }^{79}$. Esses desafios estão sendo

74 Sobre o perfil das ações de classe nas décadas de 1960 e 1970 nos Estados Unidos, remete-se a FISS, Owen. A Teoria Política das Ações Coletivas. Um Novo Processo Civil: Estudos norte-americanos sobre jurisdição, constituição e sociedade. Trad.: Carlos Alberto de Salles. São Paulo: RT, 2004. pp. 242-249.

75 HENSLER, Deborah R., PACE, Nicholas M, DOMBEY-MOORE, Bonita, GIDDENS, Beth, GRONS, Jennifer, MOLLER, Erik K. Class Action Dilemmas: Pursuing Public Goals for Private Gain. Santa Mônica: Rand Institute for Justice, 2000. p. 12.

76 HENSLER, Deborah R. The Globalization of Class Action: an Overview. In: HENSLER. Op. cit. p.8-9.

77 SHERMAN, Edward F. "Abandoned Claims" in Class Actions: Implications for Preclusion and Adequacy of Counsel. George Washington Law Review. Pensilvânia: George Washington Law School, v. 79, n. 783, fev. 2011. p. 484.

78 Como é o próprio autor, e não o advogado, que define o objeto do litígio nas classactions, as associações de advogados dos estados norte-americanos têm estabelecido um código de ética que cabe ao advogado alertar o seu cliente sobre sua postura na condução de uma ação coletiva, até porque muitas vezes é difícil definir claramente quais são os objetivos da classe para a propositura da ação coletiva (Sobre o tema: RHODE, Deborah L. Class Conflicts in Class Actions. Stanford Law Review. Califórnia: Stanford Law School, v. 34, n. 6, jul. 1982. p. 1.183).

79 Sobre o tema: HENSLER, Deborah R. Third-Party Financing of Class Action in the United States: Will the Sky Fall? De Paul Law Review. Chicago: De Paul Law School, v. 63, n. jan, 2014. pp. 1101-1128. 
enfrentados no desenvolvimento de proposta de alteração das regras do direito processual civil, aí incluindo também o aprimoramento de disposições da Regra 23, sobre ações coletivas, ainda em fase de consultas públicas.

Já as ações coletivas no âmbito dos países membros da União Europeia acabaram recentemente influenciadas pela Recomendação de 11 de junho de 2013,da Comissão Europeia ${ }^{80}$ sobre os princípios comuns que devem reger os mecanismos de tutela coletiva inibitórios e indenizatórios no âmbito dos Estados Membros em relação às violações de direitos garantidos pelo bloco. A referida recomendação foi editada no mesmo dia da comunicação ao Parlamento Europeu, ao Conselho, ao Comitê Econômico e Social Europeu e ao Comitê das Regiões ${ }^{81}$ e destaca, a partir da relevância de assegurar o acesso à Justiça, a utilização do processo coletivo como mecanismo adequado para prevenir e punir violações ao direito do consumidor, da concorrência, da proteção do meio ambiente, de dados, de serviços financeiros e dos investidores, com o estabelecimento de um modelo comum para as ações coletivas no âmbito europeu. Destaca, ainda, a necessidade dos Estados-Membros adotarem medidas para a implementação da recomendação, que devem ocorrer até 26 de julho de 2015, com as estatísticas judiciais e extrajudiciais apresentadas no ano seguinte, para reavaliação da recomendação até 26 de julho de 2016.

A Recomendação assegura tanto uma tutela inibitória como uma tutela ressarcitória, que devem ser previstas por todos os países membros e trouxe duas disposições sobre os legitimados: uma no âmbito de ações coletivas no bloco e outra especificamente para os casos de ações coletivas transfronteiriças.

No primeiro caso, regulou apenas sobre requisitos que devem ser preenchidos pelas entidades representativas, sem prejuízo de outras exigências nos direitos nacionais. O primeiro requisito é a entidade não possuir fins lucrativos; o segundo é a existência de uma relação direta entre os objetivos principais da entidade e os direitos cuja tutela se pretende, o que se denomina pertinência temática, e o terceiro requisito é a entidade ser dotada de capacidade, tanto econômica, como de suporte humano e de conhecimentos jurídicos para o litígio. Já se a entidade não for cadastrada, caberá às autoridades governa-

80 MENDES, Aluisio Gonçalves de Castro, SILVA, L. C. P. "A Recomendação da União Europeia, de 11 de junho de 2013, sobre as ações coletivas". Revista del Instituto Colombiano de Derecho Procesal. Colômbia: Instituto Colombiano del Derecho Procesal, v. 1, 2014. pp. 325-343.

81 UNIÃO EUROPEIA. Rumo a um quadro jurídico horizontal europeu para a tutela coletiva. Disponível em https://toad.eesc.europa.eu/ViewDoc.aspx?doc.2013_00_00. [Acesso em 12 abr. 2014]. 
mentais, ou ao próprio tribunal, realizarem uma certificação ad hoc para o ajuizamento de uma ação.

No segundo caso, ao tratar dos casos transfronteiriços, no art. 17, admite-se a legitimidade de entidades representativas estrangeiras ou de grupos estrangeiros, desde que sejam designados por algum Estado membro como legitimados para as ações coletivas (art. 18).

O texto não aborda propriamente a necessidade de um processo de certificação de uma ação como coletiva, até mesmo porque não há uniformidade sobre o tema no âmbito do bloco ${ }^{82}$ e trata, nos artigos $8^{\circ}$ e $9^{\circ}$, apenas que se verifique a presença de condições para a ação coletiva, sem especificar que condições são essas. Essa verificação é atribuída como função de cada tribunal, para indeferir, de plano, ações manifestamente infundadas.

A Recomendação traz, ainda, formas judiciais e extrajudiciais para a solução de conflitos coletivos, que serão abordadas dentro do contexto da terceira onda renovatória de Mauro Cappelletti, fortalecendo as ações coletivas, que possuíam, ainda, pouco destaque à época do Projeto Florença. Ressalte-se, aliás, que o fortalecimento das ações coletivas significa o aprimoramento do resultado de suas funções, que colaboram na solução de muitos problemas apontados há quarenta anos por Mauro Cappelletti. As ações coletivas possuem um importante papel ${ }^{83}$ no acesso à Justiça.

Apesar de um Poder Judiciário assoberbado, e com recursos materiais e humanos insuficientes, diversas lesões ainda não são levadas ao Poder Judiciário. Trata-se das lesões de bagatela, retratadas como entrave ao acesso à Justiça pelo Projeto Florença, que, se consideradas separadamente, em termos econômicos, são de pequena monta, fazendo com que, na relação custo-benefício, o ajuizamento de ações individuais seja desestimulante e, até mesmo, deficiente, deixando perpetuar práticas ilegais e lesivas. Considerando que, tanto na esfera pública, como na privada, as relações de massa expandem-se continuamente, os causadores das lesões acabam beneficiados, pois, além de geralmente terem mais recursos para despender no litígio, acabam se beneficiando das lesões perpetradas

82 Em relação aos diferentes modelos adotados para as ações coletivas: MENDES, Aluisio Gonçalves de Castro. Ações coletivas e meios de resolução coletiva de conflitos no direito comparado e nacional. 4.ed. São Paulo: RT, 2014, p. 49-195 e SILVA, Larissa Clare Pochmann da. A Legitimidade do Indivíduo nas Ações Coletivas. Rio de Janeiro: GZ, 2013. pp. 5-81.

83 Sobre o papel das ações coletivas: MENDES, Aluisio Gonçalves de Castro. Ações coletivas e meios de resolução coletiva de conflitos no direito comparado e nacional. 4.ed. São Paulo: RT, 2014. pp. 33-44. 
em relação aos poucos que buscam sua reparação no Poder Judiciário. Como consequência, de pouca ou nenhuma valia passam a ser as normas de direito material, que estabelecem direitos para os lesados, se a referida proteção não encontrar amparo processual.

Ademais, o causador da lesão, em tese, com mais recursos materiais e humanos, estará mais bem preparado para o embate do que os que buscam amparo no Poder Judiciário, ocasionando o desequilíbrio na relação processual. Esse desequilíbrio pode ser agravado pela falta de formação e informação jurídica, como já tinha constatado Cappelletti na conclusão de suas pesquisas.

As ações coletivas representam uma importante ferramenta para o acesso à Justiça, eliminando os entraves mencionados. O valor patrimonial que individualmente seria ínfimo, coletivamente passa a ser relevante ${ }^{84}$, permitindo as ações coletivas que esses danos não fiquem sem reparação ${ }^{85}$. O legitimado coletivo terá, ainda, uma posição mais equilibrada no litígio, e sua representatividade adequada será presumida por disposição legal ou aferida no caso concreto, dependendo do modelo adotado. O sistema também acabará por definir seu potencial econômico para atuação. Além disso, a ação coletiva poderá assegurar a importância política de algumas causas, como direitos das minorias, direitos civis e do meio ambiente.

É preciso afirmar, ainda, que essa multiplicação de causas idênticas pode gerar decisões contraditórias, e, às vezes, até mesmo antagônicas. Demandantes com situações idênticas do ponto de vista do direito material podem acabar recebendo respostas jurisdicionais diferenciadas, decorrente apenas da relação processual. O direito processual acaba por assumir, nessas situações, um papel determinante, e não meramente instrumental, o que gera desigualdade e grande insegurança jurídica. As ações coletivas podem contribuir para a atenuação desse problema, com a resolução da questão em um único processo.

Cabe, ainda, destacar a relevância das ações coletivas no cumprimento do direito material. Se poucas pessoas buscam a satisfação do direito, as condenações impostas poderão ser insuficientes para coibir o ato ilícito. O papel das ações coletivas vai além de assegurar a reparação dos danos para todos os lesados, ou, pelo menos de uma quantidade significativa de vítimas, pretendendo fazer

84 ALVAREZ, Alejandro Bugallo. "Análise Econômica do Direito: contribuições e desmitificações". Revista Direito, Estado e Sociedade. Rio de Janeiro: PUC-Rio, v. 9, n. 29, jul.-dez. 2006. p. 54.

85 DEFFAINS, Bruno, DORIAT-DUBAN, Myriam, LANGLAIS, Éric. Economie des actions collectives. Paris: Presses Universitaires de France (PUF), 2008. pp. 20-21. 
cessar o dano e alterar a postura nociva à sociedade. Permite, ainda, um ganho pela correção na postura das empresas, que, considerando os impactos de uma condenação em um processo coletivo em seu balanço, de terem de indenizar essa quantidade significativa de vítimas, acabarão compelidas a uma correção na sua atuação, de forma que passe a respeitar as normas de direito material ${ }^{86}$.

Porém, não são apenas as ações coletivas se desenvolvem no cenário estrangeiro, como também os mecanismos de solução coletiva de conflitos. Nos Estados Unidos, o Multidistrict Litigation Panel tem sua previsão no ordenamento jurídico desde $1968^{87}$ e atualmente conta com 7 (sete) juízes, sendo um presidente, para a solução coletiva de $\operatorname{conflitos}^{88}$. Na Alemanha89, sob a inspiração das test claims foi incorporada, em 1991, ao Estatuto alemão da Jurisdição Administrativa (Verwaltungsgerichtsordnung), a solução coletiva de conflitos, sob a denominação de procedimento-padrão (Musterverfahren). Em seguida, em 2000, a Inglaterra edita seu primeiro Código de Processo Civil, com a previsão das decisões de litígios de grupo (Group Litigation Order), ao lado da própria demanda-teste (testclaim). Mas, em 2005, uma nova versão de Musterverfahrené criada na KapMuG (Lei sobre o Procedimento-Modelo nos conflitos jurídicos do mercado de capital), com vigência temporária, inicialmente até outubro de 2010, mas que foi prorrogada até outubro de 2012 e, em seguida, prevista até 01/11/2020. E, também em 2008, nos moldes da primeira espécie de Musterverfahren e praticamente repetindo o texto do $\mathbb{\$}^{93 a}$ da Verwaltungsgerichtsordnung, o procedimento-modelo também é adotado no ramo jurisdicional alemão, que cuida da assistência e previdência social (Sozialgerichtsgesetz).

Esses mecanismos objetivam trazer isonomia e segurança jurídica diante da multiplicidade de questões comuns, no cenário internacional consideradas sem a dicotomia entre de fato e de direito, evitando-se que a proliferação de questões comuns se proliferem, assolando o Poder Judiciário de diversos países e podendo gerar decisões contraditórias, complementando, na atualidade, o que foi considerada por Cappelletti como a segunda onda renovatória de acesso à Justiça.

86 COHEN, Dany. Droit et Économe Du Procés Civil. Paris: L.G.D.J., 2010. p. VII. HERR, David F. Multidistrict Litigation Manual: Practice Before the Judicial Panel on Multidistrict Litigation. Minnesota: Thomson Reuters, 2014. p. 9. As informações atualizadas podem ser obtidas no sítio eletrônico do mecanismo, em http://www.jpml.uscourts.gov/panel-presentations-0. [Acesso em 26 dez. 2014]. 


\section{UMA RELEITURA DA TERCEIRA ONDA} RENOVATÓRIA: O APERFEIÇOAMENTO DA TÉCNICA JUDICIAL E A SOLUÇÃO EXTRAJUDICIAL DE CONFLITOS.

A terceira onda renovatória no Brasil teve sua implementação paulatina. Cabe destacar, dentre os instrumentos de aperfeiçoamento da técnica judicialno cenário brasileiro que, em 13 de dezembro de 1994, a Lei no 8.952 introduziu no ordenamento jurídico brasileiro a figura da tutela antecipada, afastando, uma vez preenchidos os requisitos para a sua concessão, o risco que o direito das partes pereça diante do tempo que levaria até o julgamento. Foi um instrumento relevante, criado porque " a ordem jurídica se vê posta em perigo iminente, de tal sorte que o emprego das outras formas de atividade jurisdicional provavelmente não se revelaria eficaz, seja para impedir a consumação da ofensa, seja mesmo para repará-la de modo satisfatório" ${ }^{\prime 0}$.

Em 1988, Carta Magna, nos artigos 24, X, e 98, I, previu os juizados especiais. Essa previsão foi reconhecida como a possibilidade de trazer ao Poder Judiciário uma parcela da população que se afastava em determinadas causas pela formalidade e burocracia tradicionalmente associadas à estrutura. Os dispositivos ensejaram, anos mais tarde, a lei no $9.099 / 95$, que instituiu os Juizados Especiais Cíveis no âmbito estadual; a lei no $10.259 / 2001$, que instituiu os Juizados Federais e a lei $n^{\circ} 12.153 / 2009$. A finalidade principal dos Juizados Especiais Cíveis é facilitar o acesso à justiça, especialmente por se revelarem como a experiência de justiça de grande parte da população $0^{6}$, sem tentarem resolver a problemática dos juízos comuns ${ }^{7}$.Os Juizados são regidos pelos princípios da oralidade, da simplicidade, da informalidade, da economia processual e da celeridade, e do estímulo à conciliação ou à transação, trazendo figuras já previstas por Mauro Cappelletti e merecem destaque as figuras do conciliador e do juiz leigo, que auxiliam o juiz togado e trazem uma nítida tentativa de aproximar o Poder Judiciário da sociedade ${ }^{91}$.

90 BARbOSA MOREIRA, José Carlos. O Novo Processo Civil Brasileiro. 29. ed. Rio de Janeiro: Forense, 2012. p. 309.

91 Como esclarece Cândido Rangel Dinamarco, "tais novos sujeitos processuais, estranhos ao quadro da Justiça e não integrando o Estado, são um elo entre este e o indivíduo. Não exercem jurisdição, não são portadores do poder estatal como o juiz. São membros da comunidade, chamados a integrar aquela - participativa e pluralista preconizada por Kazuo Watanabe, num relacionamento menos formal com os litigantes" (DINAMARCO, Cândido Rangel. Fundamentos do processo civil moderno. São Paulo: Malheiros, 2001. p. 1427). 
Também em 1998, a Lei n 9.756 conferiu nova redação ao art. 120, parágrafo único; ao art. 544, $\$ 3^{\circ}$ (posteriormente alterado pela Lei $\mathrm{n}^{\circ} 12.322 / 2010$ ) e ao art. 557, todos do Código de Processo Civil, para que: 1) com previsão no art. 120, parágrafo único, o relator possa julgar de plano o conflito de competência, desde que haja jurisprudência dominante no tribunal sobre o conflito suscitado; 2) nos casos de agravo em face de decisão que indeferiu a remessa do recurso ao STJ, a possibilidade do relator dar provimento ao recurso especial, desde que a decisão recorrida esteja em confronto com súmula ou jurisprudência dominante do STJ, de acordo com a redação conferida em 1998; 3) o relator possa negar seguimento monocraticamente ao recurso em confronto com súmula ou jurisprudência dominante do respectivo tribunal, do STF ou de Tribunal Superior ou, ainda, dar provimento monocraticamente ao recurso caso a decisão recorrida esteja em desconformidade com súmula ou jurisprudência dominante do STF ou de Tribunal Superior.

Posteriormente, em 2004, a Emenda Constitucional 45 alterou o art. 102, $\$ 2^{\circ}$ da Constituição Federal e acrescentou o art. 103-A ao texto constitucional, criando a súmula vinculante, que tem observância obrigatória perante os juízes, tribunais e a Administração Pública, sob pena de reclamação direta ao STF. Em relação ao primeiro dispositivo, previu-se o efeito vinculante nas hipóteses de decisões definitivas de mérito, proferidas pelo STF, nas ações diretas de inconstitucionalidade e nas ações declaratórias de constitucionalidade.Quanto ao segundo dispositivo, teve-se, a partir de então, a previsão de súmulas vinculantes no ordenamento jurídico brasileiro, trazendo previsibilidade e uniformidade aos julgamentos, com o reforço da ideia de observância obrigatória dos precedentes fixados pelos tribunais superiores, inicialmente existente apenas nos sistemas de common law.

Em 2006, a Lei $\mathrm{n}^{\circ} 11.276$ renumerou o art. 518 do $\mathrm{CPC}$ o $\$ 1^{\circ}$, para dispor que o juiz não receberá o recurso de apelação quando a sentença estiver em conformidade com súmula do STJ ou do STF.

No mesmo ano, a Lei no 11.277 incluiu o art. 285-A no Código de Processo Civil, que permite ao juiz de primeiro grau o julgamento, de plano, de improcedência, antes mesmo da citação do réu, quando houver casos idênticos já sentenciados no juízo, aí sendo interpretado de modo sistemático o dispositivo para que essa autorização ocorra quando, sobre a questão de direito, houver súmula ou jurisprudência dos Tribunais Superiores.

Ainda em 2006, a Lei ${ }^{\circ} 11.418$ acrescentou os artigos 543-A e 543-B ao Código de Processo Civil, que tratam da repercussão geral e do recurso extraordinário repetitivo e, em 2008, a Lei n 11.672 acrescentou ao Código de Processo Civil o artigo 543-C, tratando da sistemática do recurso especial repetitivo, de forma que não chegassem inúmeros recursos versando sobre a mesma questão 
aos tribunais superiores, evitando que, além de abarrotá-los, houvesse decisões contraditórias.

Em 2010, a Lei $\mathrm{n}^{\circ} 12.322$ tratou do agravo interposto contra decisão que não admite recurso extraordinário ou especial em agravo nos próprios autos, alterando alguns dispositivos do $\mathrm{CPC} / 73$, dentre eles o artigo 544, em seus parágrafos primeiro e terceiro, além de acrescentar o parágrafo quarto ao dispositivo. A alteração permitiu que o relator, no Supremo Tribunal Federal ou no Superior Tribunal de Justiça, negue seguimento ao recurso manifestamente inadmissível, prejudicado ou em confronto com súmula ou jurisprudência dominante no tribunal ou, ainda, dê seguimento ao recurso, se o acórdão recorrido estiver em confronto com súmula ou jurisprudência dominante no tribunal.

Porém, o aperfeiçoamento da técnica judicial não se esgota aí. Em dezembro de 2014, foi aprovado no Senado Federal, casa iniciadora do projeto, o novo Código de Processo Civil, sancionado no dia 16 de março de 2015, com vacatiode um ano. O novo Código busca, em diversos pontos, o aperfeiçoamento da técnica judicial. Segundo divulgado pelo Senado Federal ${ }^{92}, 13$ seriam as suas diretrizes: 1) ações judiciais com o mesmo objetivo poderão ser as suas teses jurídicas julgadas de uma única vez (incidente de resolução de demandas repetitivas) ; 2) o novo $\mathrm{CPC}$ extingue alguns recursos, limita outros e encarece a fase recursal, além de criar multas quando o objetivo for apenas para atrasar a decisão; 3) as ações serão julgadas em ordem cronológica de conclusão e a lista de processos ficará disponível para consulta pública; 4) juízes terão que detalhar os motivos das decisões, não podendo apenas transcrever a legislação que dá suporte à sentença; 5) com o objetivo de tentar acordos, os tribunais terão que criar centros judiciários de conciliação e mediação, com profissionais especializados.; 6) a presença de especialista na tomada de depoimento de criança ou incapaz passa a ser obrigatória nos casos relacionados a abuso ou alienação parental; 7) fica mantida a prisão fechada para o devedor de pensão, mas agora com a garantia de que ficará separado dos presos comuns; 8) para garantir a execução da sentença, o juiz poderá determinar a inclusão do nome do devedor em cadastros de inadimplentes; 9) administradores e sócios passam a responder com seus bens pelos prejuízos das sociedades com personalidade jurídica em casos de abusos e fraudes; 10) advogados públicos poderão receber, além do salário, honorários quando obtiverem sucesso nas causas; 11) advogados liberais, nas ações vencidas contra a Fazenda Pública, terão tabela de honorários

92 BRASIL. Os 13 Principais Pontos do Novo Código de Processo Civil. Disponível em http:// senadofederal.tumblr.com/post/105602565077/os-13-principais-pontos-do-novocodigo-de-processo. [Acesso em $17 \mathrm{dez}$. 2014]. 
de acordo com faixas sobre o valor da condenação ou do proveito econômico; 12) para que os advogados tenham férias e não percam prazos, os processos ficam suspensos entre 20 de dezembro e 20 de janeiro e 13) a intervenção do amicuscuriae em causas controversas e relevantes poderá ser feita por uma pessoa, órgão ou entidade que detenha conhecimento ou representatividade na discussão.

Contudo, importante destacar que esse histórico de reformas para o aperfeiçoamento da técnica judicial não foi capaz de inibir o número de processos em tramitação no Poder Judiciário. Segundo dados do CNJ para o ano de 2014, com base no ano de $2013^{93}$, havia 95,14 milhões de processos no Poder Judiciário em tramitação, sendo que 70\% deles, isto é, 66,8 milhões de casos já estavam pendentes desde o início de 2013, com o ingresso de 30\% de novos casos - 28,3 milhões de processos. Em 2013, com base no ano de $2012^{94}$, havia 72 milhões de casos tramitando na Justiça Estadual, sendo 22 milhões de casos novos e 50 milhões de casos pendentes; na Justiça Federal foram 11,2 milhões de processo em tramitação, sendo 3,1 milhões de novos casos e 8,1 milhões de casos pendentes.

Nos tribunais superiores, de acordo com dados oficiais divulgados no endereço eletrônico do Supremo Tribunal Federal, houve um aumento grande e constante do número de casos apresentados ao longo de sua história. O crescimento foi de cerca de cinquenta a cem por cento a cada década, no período de 1950-1990. No período entre os anos de 1990 e 2000, houve um aumento de quatro por cento de novos casos a cada ano, o que permitiu, nesse intervalo, um aumento de 18.564 para 105.307 de casos registrados por ano. Note-se que o período coincide com a democratização e após a entrada em vigor da Constituição de 1988 anos, destacando que os casos em primeira instância na década de 1990 chegaram ao Supremo Tribunal de cerca de dez anos mais tarde. O aumento, ainda que em proporções muito menores, continuou nos anos seguintes até 2006, quando a Suprema Corte recebeu 127.535 casos.

Começa a partir de 2007 e dura até 2011 uma diminuição gradual e relativamente substancial no número de casos registrados no Supremo Tribunal

93 Dados disponíveis em BRASIL. CNJ. Lançamento do Relatório Justiça em Números 2014. Brasília, DF: CNJ, 2014. Disponível em http://www.cnj.jus.br/programas-de-a-a-z/ eficiencia-modernizacao-e-transparencia/pj-justica-em-numeros/relatorios. [Acesso em 28 out. 2014].

94 Os dados podem ser encontrados em BRASIL. CNJ. Lançamento do Relatório Justiça em Números 2013. Brasília, DF: CNJ, 2013. Disponível em http://www.cnj.jus.br/evento/ eventos-novos/lancamento-do-relatorio-justica-em-numeros-2013/apresentacoes. [Acesso em 23 jun. 2014]. 
Federal, coincidindo com a entrada em vigor da exigência de repercussão geral e do procedimento de recurso repetitivo previsto nos artigos 543-A e B do Código. Em 2007, existiam 119.324; 100.781 em 2008, seguido de 84.369 em 2009; 71.670 em 2010; 64.018 autuados em 2011 e 72.072 processos autuados em 2013, sendo que apenas 38.109 e 44.170 foram distribuídos em 2011 e em 2013, respectivamente. O acervo do Supremo Tribunal Federal, em 31/12/2014 contava com 56.677 processos e, até $31 / 01 / 2015$, já foram recebidos 3.693 processos.

No Superior Tribunal de Justiça, dados divulgados em seu endereço eletrônico indicam que houve também um crescimento entre a sua criação em 1989 e 2007. Como exemplo, em 1989 havia apenas 6.103 casos; em 1990, 14.087; 92.107 casos em 1998, passando para um nível de 238.982 em 2003, e finalmente, para 313.365 em 2007. As alterações nos anos seguintes não mostram uma diminuição linear como ocorreu no Supremo Tribunal Federal. No Superior Tribunal de Justiça, houve uma diminuição em 2008 para 271.521 casos, mas em 2009, cresceu para 292.103 processos novamente, caindo novamente em 2010 para 228.981. Em 2011, no entanto, o número voltou a aumentar, atingindo um valor recorde de 338.394 processos distribuídos e, em 2013, esse número foi de 309.677 processos, tendo sido alcançado, em 2014, o quantitativo de 314.316 processos distribuídos. Atualmente, há 914 questões afetadas ao recurso repetitivo no STJ, tendo como base a data de 19/12/2014, sendo que 894 tiveram seu mérito julgado.

O aperfeiçoamento da técnica judicial, porém, não é suficiente se não for incentivada a transição de uma cultura demandista para uma cultura pacificadora $^{95}$. Nessa perspectiva, além da conciliação, o Novo Código de Processo Civil incentiva, a mediação como técnica para a solução consensual de conflitos, com a realização de sessões e audiências de conciliação e mediação, dispondo que essas técnicas devem ser incentivadas por todos os membros do Poder Judiciário.

Paralelamente a essas medidas, tramitou no Poder Legislativo e já foi remetido para sanção o PL 7169/2014, que dispõe sobre a mediação entre particulares como o meio alternativo de solução de controvérsias e sobre a composição de conflitos no âmbito da Administração Pública e a Lei no 13.129/2015, que reforma alguns dispositivos da lei da arbitragem (Lei $\mathrm{n}^{\circ}$ 9.307/96), ampliando o âmbito de aplicação da arbitragem e dispondo sobre a escolha dos árbitros quando as partes recorrem a órgão arbitral, a interrupção da prescrição pela instituição da arbitragem, a concessão de tutelas cautelares e de urgência nos casos de arbitragem, a carta arbitral, a sentença arbitral e o incentivo ao estudo

95 CALMON, Petrônio. Fundamentos da mediação e da conciliação. 2. ed. Brasília: Gazeta Jurídica, vol. 1, 2013. 
do instituto da arbitragem. O objetivo de ambos os projetos é o fortalecimento dos mecanismos de solução de conflitos.

Em relação ao direito estrangeiro, de forma geral, afirmava-se que o processo civil poderia ser dividido em dois grupos: o dos países da civil lawe o dos países da common law, com a adoção do sistema adversarial ou inquisitorial. Os países de common Law geralmente adotavam o cenário adversarial, com uma flexibilização do procedimento pelas partes e seus advogados, e o sistema da civil law, por outro lado, os processos seguem a regra estatal, conduzidos pelo juiz, com a possível responsabilização dos sujeitos do processo e dos auxiliares do juízo por sua atuação ${ }^{96}$. No sistema de civil law, há, ainda, uma hierarquia nos tribunais e prevalece a tendência à especialização, além de haver uma estrutura separada para demandas de pequeno valor, enquanto no sistema de common law, embora haja alguma especialização - como, por exemplo, em matéria de direito de família-, prevalece a hierarquia em relação a um único tribunal.

É certo com a aproximação dos sistemas de common lawe de civil law, essas diferenças tendem a diminuírem, mas os aperfeiçoamentos da técnica legislativa que ocorreram nos dois sistemas não foram suficientes para conter o grande quantitativo de demandas capaz de assoberbar o Poder Judiciário de cada país. Por exemplo, tendo como base o período entre os anos de 2010 e $1^{\circ}$ de janeiro de 2012, na Itália, não houve alteração nos recursos humanos disponíveis no Poder Judiciário (o país manteve seu número de varas especializadas e não especializadas, sendo 1231 varas não especializadas e 87 especializadas), mas, enquanto havia 4.986.193 demandas de matéria não criminal pendentes de julgamento, ingressaram mais 4.010.588 novos casos no Poder Judiciário italiano. Já na França, em que pese um pequeno aumento nos recursos humanos do Poder Judiciário (de 774 para 778 varas não especializadas e de 1157 para 1156 varas especializadas no mesmo período), havia 1.654 .187 demandas não criminais pendentes de julgamento no Poder Judiciário francês eingressaram 1.688.927 casos em matéria não criminal97, para se somaram aos casos pendentes. Com base nesses dados, pode-se notar que a grande quantidade de demandas assoberba o Poder Judiciário de diversos países, não sendo peculiar à realidade brasileira.

96 CHASE, Oscar G., HERSHKOFF, Helen, SILBERMAN, Linda, TANIGUCHI, Yasuhei, VARANO, Vicenzo, ZUCKERMNA, Adrian. Civil Litigation in Comparative Context. St. Paul: Thomson West, 2007. pp. 3-6.

97 EUROPEAN COMISSION FOR THE EFFICIENCY OF JUSTICE (CEPEJ). Study on the functioning of judicial systems in the EU Member States: facts and figures from the CEPEJ 2012-2014 evalution exercise, p.52. Para compreender como foram coletados os dados e $\mathrm{s}$ peculiaridades de cada sistema, recomenda-se o acesso à pesquisa em sua íntegra, que totaliza 993 páginas. 
Uma pesquisa realizada no âmbito da União Europeia, por exemplo, apontou que, somente no ano de 2014, 8 países anunciaram reformas processuais ou estão com elas em curso, mas, na primeira instância, do ajuizamento da ação até a prolação da sentença, como consequência desse grande volume de processos, uma demanda cível, ainda em 2013, demorava, em média, 300 dias para ser julgada na França e 600 dias na Itália ${ }^{98}$.

Porém, também no direito estrangeiro tem se incentivado os mecanismos extrajudiciais para a solução de conflitos, tanto para direitos individuais e, especialmente, para direitos coletivos. Nos Estados Unidos, por exemplo, valoriza-se, sempre que possível, a utilização e o aperfeiçoamento das técnicas de mediação nos escritórios modelo das faculdades de direito, de forma que não seja necessário ingressar no Judiciário para resolver a questão levada pelo interessado, e proliferam-se os julgamentos de arbitragens coletivas, com destaque para os casos de arbitragem coletiva analisados pela Suprema Corte Norte-Americana ATE T Mobility v. Concepcion131 S.Ct. 1740 (2011), American Express Co. et al. v. ItalianColorsRestaurant, 133 S.Ct. 2304 (2013), Carmax Auto Superstores v. Fowler,_S.Ct._, 2014 WL 684014 (Feb. 24, 2014) ${ }^{99}$, em que se analisou desde a validade de uma cláusula que preveja a submissão de consumidores a uma arbitragem coletiva, passando pelos altos custos do sistema para cada indivíduo até a arbitragem coletiva em matéria trabalhista. Estas questões, apesar de acontecerem nos Estados Unidos, não estão tão distantes de afetarem a realidade brasileira: basta lembrar que esse ano, o Dropbox, um armazenamento virtual de dados, comunicou a todos os seus usuários que, a partir de 2014, devido a uma alteração contratual, sua cláusula contratual passaria a prever a solução de eventuais conflitos através da arbitragem coletiva, oportunizando, aos que não concordassem, o opt out. Considerando que o programa dispõe de milhares de usuários em todo o mundo, seus impactos serão para muito além das fronteiras norte-americanas.

Já na Europa, a valorização da solução extrajudicial, especialmente de forma consensual, de conflitos ocorreu a partir da edição da Diretiva 52, de 21 de maio de 2008 pelo Parlamento Europeu, que dispôs sobre a mediação em matéria civil e comercial, objetivando facilitar o acesso à resolução alternativa de litígios e em promover a resolução amigável de litígios, incentivando o recurso à mediação

98 COMISSÃO EUROPEIA. Painel de Avaliação da Justiça na UE de 2015. Bruxelas: Comissão Europeia, 9 mar. 2015. Disponível em: http://ec.europa.eu/justice/effectivejustice/files/justice_scoreboard_2015_pt.pdf. [Acesso em 14 jun. 2015].

99 Para uma análise sobre o tema: PARK, Willian W. The Politics of Class Arbitration: Jurisdictional Legitimacy and Vindication of Contract Rights. American University International Law Review. Massachussets: American University, vol. 27, ano 4, 2012. pp. 837-869. 
e assegurando uma relação equilibrada entre a mediação e o processo judicial. Paralelamente a esta iniciativa, anos depois, a Recomendação de 11 de junho de 2013.

Um dos destaques da Recomendação é a previsão da mediação, com possibilidade de realização antes do processo ou em seu curso, desde que haja consentimento das partes, na busca da compensação de danos. A proteção do consumidor é compreendida como o cenário mais propício à aplicação dos meios alternativos, mas, a partir do texto da recomendação, espera-se implementar a mediação em áreas também como a de direitos trabalhistas e no direito ambiental ${ }^{100}$, fortalecendo-se a solução de conflitos em áreas que foram destacadas pelo Projeto Florença.

Nesse sentido, a terceira onda renovatória, hoje, combina o aperfeiçoamento da técnica judicial com o incentivo a técnicas extrajudiciais de solução de conflitos e aplica-se tanto a direitos individuais como a direitos coletivos, mas todos esses avanços não foram capazes de conter o aumento do quantitativo de processos. Ainda é necessária uma maior preocupação com o aperfeiçoamento da técnica judicial, especialmente com a resolução coletiva de conflitos, e com o incentivo à solução extrajudicial de conflitos, pois o mero aumento de recursos materiais e humanos hoje não é suficiente para responder à morosidade enfrentada no Poder Judiciário, decorrente do grande quantitativo de processos.

\section{CONSIDERAÇÕES FINAIS}

Quarenta anos após o início da divulgação do resultado das pesquisas obtido no Projeto Florença, o presente trabalho pretende prestar uma singela homenagem à iniciativa coordenada por Mauro Cappelletti. Embora apenas o último dos quatro volumes do projeto, em colaboração com Bryant Garth, tenha sido traduzido para o português e publicado no Brasil, a obra, em sua íntegra, é um marco para o direito processual em todo o mundo. Não se pode negar que o tema acesso à Justiça sempre foi objeto de debates, mas foi o Projeto Florença capaz de sistematizar e sintetizar os seus principais desafios.

Hoje, no Brasil, e comparativamente também no cenário internacional, podem se verificar vários avanços em relação aos entraves apontados por Mauro Cappelletti: a assistência judiciária se aperfeiçoou;as ações coletivas se fortaleceram, bem como os mecanismos de solução coletiva de conflitos; inúmeros

100 HODGES, Christopher. Developments in Collective Redress in the European Union and United Kingdom 2010. Disponível em http://globalclassactions.stanford.edu/sites/ default/files/documents/1010\%20Class\%20Actions\%20UK\%202010\%20Report.pdf. [Acesso em 09 abr. 2014]. 
foram os avanços no aperfeiçoamento da técnica judicial e iniciou-se uma valorização das formas extrajudiciais de solução de conflitos.

Não se pode afirmar, porém, que se alcançou a superação dos problemas retratados por Cappelletti: o grande quantitativo de processos que ingressam a cada ano no Judiciário e apenas se somam a um enorme quantitativo já em tramitação indica que ainda há muitos desafios a serem enfrentados. Esses desafios não serão resolvidos como em um passe de mágica, ainda é preciso aprimorar a assistência jurídica, disponibilizando defensores em todas as comarcas, fortalecer ainda mais as ações coletivas, superando os entraves que se revelaram no cenário contemporâneo, especialmente os ligados à legitimidade e na fase de execução do processo - que, no caso do Brasil, ocorre de forma prioritariamente individual, quando deveria se priorizar a execução coletiva-, aguardar os impactos do incidente de resolução de demandas repetitivas na primeira instância e continuar aperfeiçoando a técnica judicial, além de incentivar a qualquer momento, antes ou no curso do processo, as formas alternativas de solução de litígios.

Esses são desafios para os próximos anos, para que se alcance efetividade ao acesso à Justiça, como já alertado na obra de Cappelletti. É, ainda, preciso deslocar a ênfase dos direitos formais para a justiça substantiva para uma preocupação substantiva com a administração a justiça.Pode-se, concluir, portanto, que a obra do grande mestre italiano continua atual, permanecendo os caminhos apontados na sua pesquisa como um norte para as próximas décadas.

\section{REFERÊNCIAS.}

ALVAREZ, Alejandro Bugallo. "Análise Econômica do Direito: contribuições e desmitificações". Revista Direito, Estado e Sociedade. Rio de Janeiro: PUC-Rio, v. 9, n. 29, jul.-dez, 2006. pp. 49-68.

BAETGE, Dietmar. Class Actions, Group Litigation and Other Forms of Collective Litigation, p. 17. Disponível em: http://www.law.stanford.edu/display/images/dynamic/ events_media/Germany_National_Report.pdf. [Acesso em 15 dez. 2014].

BARBOSA MOREIRA, José Carlos. O Novo Processo Civil Brasileiro. 29. ed. Rio de Janeiro: Forense, 2012.

BLEGVAD, B.M., CAMPBEL, C.M., SCHUYT, C.J. European Yearbook in Law and Sociology. The Hague: Martinus Nijhoff, 1977.

BRASIL. Os 13 Principais Pontos do Novo Código de Processo Civil. Disponível em http:// senadofederal.tumblr.com/post/105602565077/os-13-principais-pontos-do-novo-codigode-processo. [Acesso em 17 dez. 2014].

. CNJ. Lançamento do Relatório Justiça em Números 2013. Brasília, DF: CNJ, 2013. Disponível em: http://www.cnj.jus.br/evento/eventos-novos/lancamento-do-relatorio-justica-em-numeros-2013/apresentacoes. [Acesso em 23 jun. 2014]. 
Lançamento do Relatório Justiça em Números 2014. Brasília, DF: CNJ, 2014. Disponível em: http://www.cnj.jus.br/programas-de-a-a-z/eficiencia-modernizacao-e-transparencia/pj-justica-em-numeros/relatorios. [Acesso em 28 out. 2014].

CALMON, Petrônio. Fundamentos da mediação e da conciliação. 2. ed. Brasília: Gazeta Jurídica, vol. 1, 2013.

CAPPELLETTI, Mauro. Access to Justice and the Welfare State. Firenza: EuropeanUniversityInstitute, 1981

GARTH, Bryant. Access to Justice: A World Survey, vol. 1, Milão: Sitjoff and Noordhoff, 1978.

2002.

GARTH, Bryant. Acesso à Justiça. Porto Alegre: Sergio Antonio Fabris Editor, GARTH, Bryant, TROCKER, Nicolò. Rabels Zeitschrift für ausländisches und internationales Privatrecht / The Rabel Journal of Comparative and International Private Law 40. Jahrg., H. 3/4, Der Schutz des Schwächeren im Recht, 1976. p. 669-717. Disponível em: http://www.jstor.org/discover/10.2307/27876038?sid=21104927538241\&uid=3\&uid=2\&uid $=60 \&$ uid $=4579946967 \&$ uid $=70 \&$ uid $=4579946977 \&$ uid $=2134$. [Acesso em $20 \mathrm{dez} .2014$ ].

CARNEIRO, Paulo Cezar Pinheiro. Acesso à Justiça: Juizados Especiais Cíveis e Ação Civil Pública. Uma Nova Sistematização da Teoria Geral do Processo. 2.ed. Forense, 2007.

CHASE, Oscar G., HERSHKOFF, Helen, SILBERMAN, Linda, TANIGUCHI, Yasuhei, VARANO, Vicenzo, ZUCKERMNA, Adrian. Civil Litigation in Comparative Context. St. Paul: Thomson West, 2007.

COHEN, Dany. Droit et Économe Du Procés Civil. Paris: L.G.D.J., 2010.

COMISSÃO EUROPEIA. Painel de Avaliação da Justiça na UE de 2015. Bruxelas: Comissão Europeia, 9 mar. 2015. Disponível em: http://ec.europa.eu/justice/effective-justice/ files/justice_scoreboard_2015_pt.pdf. [Acesso em 14 jun. 2015].

COSTA, Susana Henriques (coord.) Comentários à lei da ação civil pública e lei da ação popular. São Paulo: Quartier Latin, 2006.

DEFFAINS, Bruno, DORIAT-DUBAN, Myriam, LANGLAIS, Éric. Economie des actions collectives. Paris: PressesUniversitaires de France (PUF), 2008.

DINAMARCO, Cândido Rangel. Fundamentos do processo civil moderno. São Paulo: Malheiros, 2001.

ECONOMIDES, Kim. "Lendo as ondas do "Movimento de Acesso à Justiça": epistemologia versus metodologia?". (Trad. Paulo Martins Garchet) In: PANDOLFI, Dulce Chaves, CARVALHO, José Murilo de, CARNEIRO, Leandro Piquet, GRYNSZPAN, Mario. Cidadania, Justiça e Violência. Rio de Janeiro: Fundação Getúlio Vargas Editora, 1999. p. 61-76.

EUROPEAN COMISSION FOR THE EFFICIENCY OF JUSTICE (CEPEJ). Study on the functioning of judicial systems in the EU Member States: facts and figures from the CEPEJ 2012-2014 evalution exercise. Estrasburgo: CEPEJ, 2014.

EUROPEAN JUDICIAL NETWORK IN CIVIL AND COMMERCIAL MATTERS - England and Wales. Disponível em: http://ec.europa.eu/civiljustice/legal_aid/legal_aid_ eng_en.htm. [Acesso em 23 dez. 2014]. 
-...-.-- France. Disponível em: http://ec.europa.eu/civiljustice/legal_aid/legal_aid_fra_ en.htm. [Acesso em 26 dez. 2014].

-.-.-- Germany. Disponível em: http://ec.europa.eu/civiljustice/legal_aid/legal_aid_ger_ en.htm. [Acesso em 23 dez. 2014].

-...-.-- Italy. Disponível em: http://ec.europa.eu/civiljustice/legal_aid/legal_aid_ita_ en.htm. [Acesso em 26 dez. 2014].

FERRARESI, Eurico. Ação popular, Ação Civil Pública e Mandado de Segurança Coletivo. Instrumentos Processuais Coletivos. Rio de Janeiro: Forense, 2009.

FISS, Owen. A Teoria Política das Ações Coletivas. Um Novo Processo Civil: Estudos norte-americanos sobre jurisdição, constituição e sociedade. Trad.: Carlos Alberto de Salles. São Paulo: RT, 2004.

GALANTER, Marc. The Travails of Total Justice. In: GORDON, Robert W; HORWITZ, Morton J. Law,Society, and History: Themes in the Legal Sociologyand Legal History of Lawrence M. Friedman. Cambridge: Cambridge University Press, 2011. pp. 103-117.

"Whythe 'Haves' Come Out Ahead: Speculationsonthelimitsof legal change". Law and Society Review. Amherst, n. 9, 1974. Disponível em: http://marcgalanter.net/documents/ papers/whythehavescomeoutahead.pdf. [Acesso em: 13 jun. 2015].

GOZZOLI, Maria Clara, CIANCI, Mirna, CALMON, Petrônio, QUARTIERI, Rita. Em Defesa de um Novo Sistema de Processos Coletivos. Estudos em Homenagem a Ada Pellegrini Grinover. São Paulo: Saraiva, 2010.

GRINOVER, Ada Pellegrini et alii. Código Brasileiro de Defesa do Consumidor. 9. ed. Rio de Janeiro: Forense Universitária, 2007.

HENSLER, Deborah H, PACE, Nicholas M., DOMBEY-MOORE, Bonita, GIDDENS, Beth, GRONS, Jennifer, MOLLER, Erik K. Class Action Dilemmas: Pursuing Public Goals for Private Gain. Santa Mônica: Rand Institute for Justice, 2000.

------, HODGES, Christopher, TULIBACKA, Magdalena. The Annals of the American Academy of Political and Social Sicente. Filadélfia: SAGE, v. 622, March 2009.

"Third-Party Financing of Class Action in the United States: Will the Sky Fall?". De Paul Law Review. Chicago: De Paul Law School, v. 63, n. jan, 2014. p. 1101-1128.

HERR, David F. Multidistrict Litigation Manual: Practice Before the Judicial Panel on Multidistrict Litigation. Minnesota: Thonson Reuters, 2014.

HODGES, Christopher. Developments in Collective Redress in the European Union and United Kingdom 2010. Disponível em: http://globalclassactions.stanford.edu/sites/default/ files/documents/1010\%20Class\%20Actions\%20UK\%202010\%20Report.pdf. [Acesso em 09 abr. 2014].

-.-.--, VOGENAUER, Stefan, TULIBACKA, Magdalena. Costs and Funding of Civil Litigation: A Comparative Study. Oxford; Portland: Oregon, 2010.

$\mathrm{KOCH}$, Harald. "Non-Class Group Litigation Under EU and German Law". Duke Journal of Comparative E International Law. Carolina do Norte: Duke Law School, 2001, v. 11. p. 355-368.

MANCUSO, Rodolfo de Camargo. Ação Civil Pública em defesa do meio ambiente, do patrimônio cultural e dos consumidores - Lei 7.347/1985 e legislação complementar. 11.ed. São Paulo: RT, 2009.

Acesso à Justiça: Condicionantes Legítimas e Ilegítimas. São Paulo: RT, 2011. 
MENDES, Aluisio Gonçalves de Castro. Ações coletivas e meios de resolução coletiva de conflitos no direito comparado e nacional. 4.ed. São Paulo: RT, 2014.

-.--.-- Ações coletivas no direito comparado. XX Congreso Mexicano de Derecho Procesal Durango, 26 a 28 de novembro de 2014. Trabalho no prelo.

-.----., SILVA, Larissa Clare Pochmann da. "A Legitimidade Ativa do Indivíduo nas Ações Coletivas”. Revista de Processo. São Paulo: RT, ano 38, vol. 220, jun, 2013. p. 33-46.

...-.-.-, SILVA, Larissa Clare Pochmann da. "A Recomendação da União Europeia, de 11 de junho de 2013, sobre as ações coletivas”. Revista del Instituto Colombiano de Derecho Procesal. Colômbia: Instituto Colombiano del Derecho Procesal, v. 1, 2014. pp. 325-343.

-.----, SILVA, Larissa Clare Pochmann da. "IRDR e Ações Coletivas: Algumas Considerações sobre a Solução Coletiva de Conflitos". Artigo no prelo.

-..-.--, SILVA, Larissa Clare Pochmann da. "Precedente e IRDR: Algumas Considerações". Artigo no prelo.

-.----., SILVA, Larissa Clare Pochmann da, ALMEIDA, Marcelo Pereira da. O novo Código de Processo Civil Comparado. Rio de Janeiro: GZ, 2015.

------, SILVA, Larissa Clare Pochmann da, ALMEIDA, Marcelo Pereira da. O novo Código de Processo Civil Comparado e Anotado. Rio de Janeiro: GZ, 2015.

-..-.--, SILVA, Larissa Clare Pochmann da, BARRETO, Susana Cadore Nunes. "A Gratuidade de Justiça e a Assistência Jurídica Gratuita no novo Código de Processo Civil”. Artigo no prelo.

NERY JR., Nelson. Princípios do Processo Civil na Constituição Federal. 5. ed. São Paulo: RT, 2005.

NUNES, Rizzatto. "A assistência judiciária e a assistência jurídica: uma confusão a ser solvida”. Saraivajur. São Paulo: Saraiva, 2004. p. 1-5.

PARK, Willian W. “The Politics of Class Arbitration: Jurisdictional Legitimacy and Vindication of Contract Rights". American University International Law Review. Massachussets: American University, vol. 27, ano 4, 2012. pp. 837-869.

ROSENN, Keith S. O jeito na cultura jurídica brasileira. Rio de Janeiro: Renovar, 1998.

RHODE, Deborah L. "Class Conflicts in Class Actions". Stanford Law Review, v. 34, n. 6, jul. 1982. pp. 1.183-1.262.

SHERMAN, Edward F. "Abandoned Claims" in Class Actions: Implications for Preclusion and Adequacy of Counsel. George Washington Law Review. Pensilvânia: George Washington Law School, v. 79, n. 783, feb. 2011. p. 483-505.

SILVA, Franklin Roger Alves, ESTEVES, Diogo. Princípios Institucionais da Defensoria Pública: de acordo com a EC 74/2013 (Defensoria Pública da União). Rio de Janeiro: Forense, 2014.

SILVA, Larissa Clare Pochmann da. A Legitimidade do Indivíduo nas Ações Coletivas. Rio de Janeiro: GZ, 2013.

UNIÃO EUROPEIA. Rumo a um quadro jurídico horizontal europeu para a tutela coletiva. Disponível em: https://toad.eesc.europa.eu/ViewDoc.aspx?doc...2013_00_00. [Acesso em 12 abr. 2014].

ZUCKERMAN, Adrian A. S. "A Reform of Civil Procedure - Rationing Procedure Rather than Access to Justice". Journal of Law and Society. Utah: Law and Society, 22, n. 155, 1995. p. 1-26. Disponível em: http://adrianzuckerman.co.uk/files/File/Economy.dr7\%20PDF\%20test. pdf. [Acesso em 21 dez. 2014]. 